\title{
ॠUSES
}

政

Prepared in cooperation with the Kootenai Tribe of Idaho and the Bonneville Power Administration

Updated One-Dimensional Hydraulic Model of the Kootenai River, Idaho-A Supplement to Scientific Investigations Report 2005-5110

Scientific Investigations Report 2011-5128

U.S. Department of the Interior

U.S. Geological Survey 
Cover: Photograph of Kootenai River, Idaho, looking downstream at the upper extent of the white sturgeon critical habitat. Photograph taken from Katka Mountain by Gary Barton, U.S. Geological Survey, February 22, 2010. 


\section{Updated One-Dimensional Hydraulic Model of the Kootenai River, Idaho-A Supplement to Scientific Investigations Report 2005-5110}

By Christiana R. Czuba and Gary J. Barton

Prepared in cooperation with the Kootenai Tribe of Idaho and the

Bonneville Power Administration

Scientific Investigations Report 2011-5128 


\title{
U.S. Department of the Interior \\ KEN SALAZAR, Secretary \\ U.S. Geological Survey \\ Marcia K. McNutt, Director
}

\author{
U.S. Geological Survey, Reston, Virginia: 2011
}

For more information on the USGS - the Federal source for science about the Earth, its natural and living resources, natural hazards, and the environment, visit http://www.usgs.gov or call 1-888-ASK-USGS.

For an overview of USGS information products, including maps, imagery, and publications, visit http://www.usgs.gov/pubprod

To order this and other USGS information products, visit http://store.usgs.gov

Any use of trade, product, or firm names is for descriptive purposes only and does not imply endorsement by the U.S. Government.

Although this report is in the public domain, permission must be secured from the individual copyright owners to reproduce any copyrighted materials contained within this report.

Suggested citation:

Czuba, C.R., and Barton, G.J., 2011, Updated one-dimensional hydraulic model of the Kootenai River, Idaho-A supplement to Scientific Investigations Report 2005-5110: U.S. Geological Survey Scientific Investigations Report 2011-5128, $36 \mathrm{p}$. 


\section{Contents}

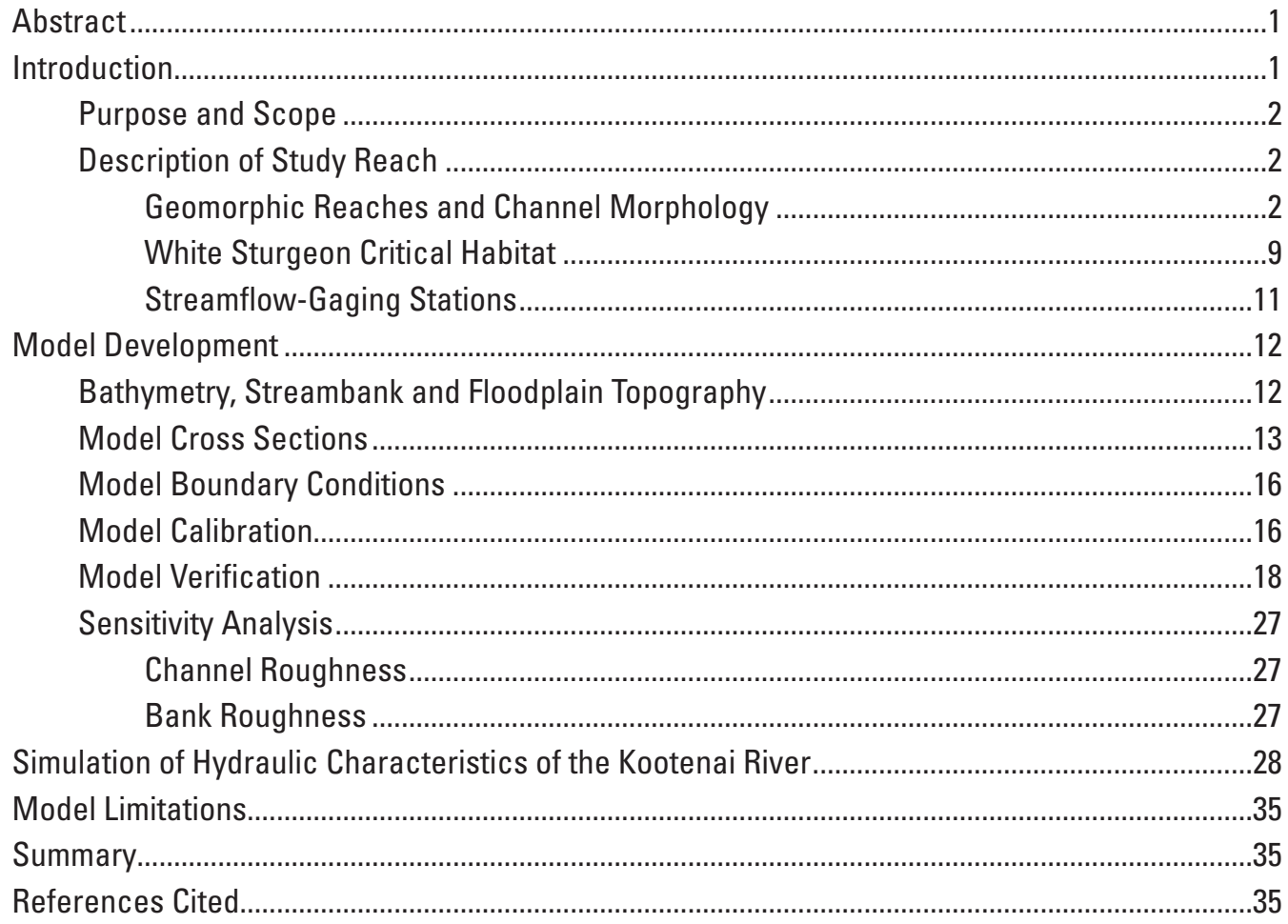

\section{Figures}

Figure 1. Map showing location of the study reach, river miles, and Kootenai River drainage basin, Idaho, Montana, and British Columbia, Canada

Figure 2. Aerial photographs showing locations of river miles and selected cross sections on the Kootenai River, Idaho

Figure 3. Aerial photograph showing location and number of white sturgeon spawning events per unit of monitoring effort on the Kootenai River near Bonners Ferry, Idaho, 1994-2001

Figure 4. Aerial photographs showing location and extent of cross sections in the study reach, Kootenai River, Idaho

Figure 5. Graph showing relative backwater conditions at Porthill gaging station (12322000) for calibration and verification events

Figure 6. Graph showing simulated and measured water-surface elevations for low-flow calibration event, March 17, 2010, on the Kootenai River, Idaho

Figure 7. Graph showing simulated and measured average velocities at cross section 143.585 relative to discharge in the study reach and water-surface elevations at Porthill gaging station (12322000)

Figure 8. Graph showing simulated and measured average velocities at cross section 153.372 relative to discharge in the study reach and water-surface elevations at Porthill gaging station (12322000) 


\section{Figures-Continued}

Figure 9. Graph showing simulated and measured average velocities at cross section 156.829 relative to discharge in the study reach and water-surface elevations at Porthill gaging station (12322000)

Figure 10. Graph showing simulated and measured average velocities at cross section 159.783 relative to discharge in the study reach and water-surface elevations at Porthill gaging station (12322000)

Figure 11. Aerial photograph of the Kootenai River showing gravel bars near Bonners Ferry, Idaho

Figure 12. Graph showing simulated water-surface elevation profiles for calibration events on the Kootenai River, Idaho

Figure 13. Graph showing simulated maximum channel depths for calibration events on the Kootenai River, Idaho

Figure 14. Graph showing simulated average velocities for calibration events on the Kootenai River, Idaho

Figure 15. Graph showing simulated water-surface elevation profiles for calibration events from RM 140 to RM 160, Kootenai River, Idaho

Figure 16. Graph showing simulated maximum channel depths for calibration events from RM 140 to RM 160, Kootenai River, Idaho 33

Figure 17. Graph showing simulated average velocities for calibration events from RM 140 to RM 160, Kootenai River, Idaho. 34

\section{Tables}

Table 1. U.S. Geological Survey streamflow-gaging stations on the Kootenai River, Idaho

Table 2. Model boundary conditions for calibration events, Kootenai River, Idaho ....... 16

Table 3. Measured and simulated water-surface elevations for calibration events, Kootenai River, Idaho

Table 4. Calibrated channel Manning's $n$ roughness values, Kootenai River, Idaho ........ 21

Table 5. Model boundary conditions for verification events, Kootenai River, Idaho ........ 22

Table 6. Measured and simulated water-surface elevations for verification events, Kootenai River, Idaho. ....

Table 7. Sensitivity of simulated water-surface elevations to changes in channel roughness coefficients for the May 16, 2007, calibration event, Kootenai River, Idaho

Table 8. Sensitivity of simulated water-surface elevations to changes in bank roughness coefficients for the June 20, 2006, high-flow calibration event, Kootenai River, Idaho 


\section{Conversion Factors and Datums}

Conversion Factors

\begin{tabular}{|c|c|c|}
\hline Inch/Pound to SI Multiply & By & To obtain \\
\hline \multicolumn{3}{|c|}{ Length } \\
\hline foot $(\mathrm{ft})$ & 0.3048 & meter (m) \\
\hline mile (mi) & 1.609 & kilometer (km) \\
\hline \multicolumn{3}{|c|}{ Area } \\
\hline square mile $\left(\mathrm{mi}^{2}\right)$ & 2.590 & square kilometer $\left(\mathrm{km}^{2}\right)$ \\
\hline \multicolumn{3}{|c|}{ Flow rate } \\
\hline foot per second (ft/s) & 0.3048 & meter per second (m/s) \\
\hline cubic foot per second $\left(\mathrm{ft}^{3} / \mathrm{s}\right)$ & 0.02832 & $\begin{array}{l}\text { cubic meter per second } \\
\left(\mathrm{m}^{3} / \mathrm{s}\right)\end{array}$ \\
\hline \multicolumn{3}{|c|}{ Hydraulic gradient } \\
\hline foot per mile ( $\mathrm{ft} / \mathrm{mi})$ & 0.1894 & $\begin{array}{l}\text { meter per kilometer }(\mathrm{m} / \\
\mathrm{km})\end{array}$ \\
\hline SI to Inch/Pound Multiply & By & To obtain \\
\hline \multicolumn{3}{|c|}{ Length } \\
\hline meter (m) & 3.281 & foot $(\mathrm{ft})$ \\
\hline kilometer $(\mathrm{km})$ & 0.6214 & mile (mi) \\
\hline \multicolumn{3}{|c|}{ Area } \\
\hline square kilometer $\left(\mathrm{km}^{2}\right)$ & 0.3861 & square mile $\left(\mathrm{mi}^{2}\right)$ \\
\hline \multicolumn{3}{|c|}{ Flow rate } \\
\hline meter per second (m/s) & 3.281 & foot per second (ft/s) \\
\hline cubic meter per second $\left(\mathrm{m}^{3} / \mathrm{s}\right)$ & 35.31 & $\begin{array}{l}\text { cubic foot per second } \\
\left(\mathrm{ft}^{3} / \mathrm{s}\right)\end{array}$ \\
\hline \multicolumn{3}{|c|}{ Hydraulic gradient } \\
\hline meter per kilometer $(\mathrm{m} / \mathrm{km})$ & 5.27983 & foot per mile $(\mathrm{ft} / \mathrm{mi})$ \\
\hline
\end{tabular}

\section{Datums}

Vertical coordinate information is referenced to the North American Vertical Datum of 1988 (NAVD 88).

Horizontal coordinate information is referenced to the North American Datum of 1983 (NAD 83).

Elevation, as used in this report, refers to distance above the vertical datum. 
This page intentionally left blank. 


\title{
Updated One-Dimensional Hydraulic Model of the Kootenai River, Idaho-A Supplement to Scientific Investigations Report 2005-5110
}

\author{
By Christiana R. Czuba and Gary J. Barton
}

\section{Abstract}

The Kootenai Tribe of Idaho, in cooperation with local, State, Federal, and Canadian agency co-managers and scientists, is assessing the feasibility of a Kootenai River habitat restoration project in Boundary County, Idaho. The restoration project is focused on recovery of the endangered Kootenai River white sturgeon (Acipenser transmontanus) population, and simultaneously targets habitat-based recovery of other native river biota. River restoration is a complex undertaking that requires a thorough understanding of the river and floodplain landscape prior to restoration efforts. To assist in evaluating the feasibility of this endeavor, the U.S. Geological Survey developed an updated one-dimensional hydraulic model of the Kootenai River in Idaho between river miles (RMs) 105.6 and 171.9 to characterize the current hydraulic conditions. A previously calibrated model of the study area, based on channel geometry data collected during 2002 and 2003, was the basis for this updated model. New high-resolution bathymetric surveys conducted in the study reach between RMs 138 and 161.4 provided additional detail of channel morphology. A light detection and ranging (LIDAR) survey was flown in the Kootenai River valley in 2005 between RMs 105.6 and 159.5 to characterize the floodplain topography. Six temporary gaging stations installed in 2006-08 between RMs 154.1 and 161.2, combined with five permanent gaging stations in the study reach, provided discharge and water-surface elevations for model calibration and verification. Measured discharges ranging from about 4,800 to 63,000 cubic feet per second ( $\left.\mathrm{ft}^{3} / \mathrm{s}\right)$ were simulated for calibration events, and calibrated water-surface elevations ranged from about 1,745 to 1,820 feet (ft) throughout the extent of the model. Calibration was considered acceptable when the simulated and measured water-surface elevations at gaging stations differed by less than $\pm 0.15 \mathrm{ft}$. Model verification consisted of simulating 10 additional events with measured discharges ranging from about 4,900 to 52,000 $\mathrm{ft}^{3} / \mathrm{s}$, and comparing simulated and measured water-surface elevations at gaging stations. Average water-surface-elevation error in the verification simulations was $0.05 \mathrm{ft}$, with the error ranging from -1.17 to $0.94 \mathrm{ft}$ over the range of events and gaging stations. Additional verification included a graphical comparison of measured average velocities that range from 1.0 to 6.2 feet per second to simulated velocities at four sites within the study reach for measured discharges ranging from about 7,400 to $46,600 \mathrm{ft}^{3} / \mathrm{s}$. The availability of high-resolution bathymetric and LIDAR data, along with the additional gaging stations in the study reach, allowed for more detail to be added to the model and a more thorough calibration, sensitivity, and verification analysis to be conducted. Model resolution and performance is most improved between RMs 140 and 160, which includes the 18.3-mile reach of the Kootenai River white sturgeon critical habitat.

\section{Introduction}

The Kootenai Tribe of Idaho (KTOI), in cooperation with local, State, Federal, and Canadian agency co-managers and scientists, is assessing the feasibility of a Kootenai River habitat restoration project in Boundary County, Idaho. The restoration project is focused on recovery of the endangered Kootenai River white sturgeon (Acipenser transmontanus) population, and simultaneously targets habitat-based recovery of other native river biota. Restoration projects under consideration include modifying the channel and floodplain, installing in-stream structures, and creating wetlands to improve the physical and biological functions of the ecosystem. River restoration is a complex undertaking that requires a thorough understanding of the river and floodplain landscape. In 2005, the U.S. Geological Survey (USGS) in cooperation with the Idaho Department of Fish and Game developed the first one-dimensional (1-D) hydraulic model of 66 river miles of the Kootenai River in Idaho (ig. 1) to characterize hydraulic conditions and determine the location of backwater extent in the study reach (Berenbrock, 2005). Other modeling efforts characterized hydraulic conditions in the braided and canyon reaches (Berenbrock, 2006), as well as sediment transport throughout the spawning reach (Berenbrock and Bennett, 2005), to aid in management 
decisions related to white sturgeon spawning. Since then, additional bathymetric surveys have been conducted between river miles (RMs) 138 and 161.4, and new stage-gaging stations were installed between RMs 154.1 and 161.2. The objective of this study was to develop an updated 1-D hydraulic model of 66 river miles of the Kootenai River in Idaho with new available data to improve accuracy and resolution. This updated model can be used to assess hydraulic characteristics of the study reach and to assist in evaluating the feasibility of habitat restoration projects.

\section{Purpose and Scope}

The purpose of this report is to document an updated 1-D hydraulic model of the Kootenai River in northern Idaho. This report includes a description of new bathymetric data collected, additional streamflow-gaging stations within the study reach, and the development and calibration of an updated 1-D hydraulic model of the study reach in the Kootenai River. Model revisions focused on improving the resolution and accuracy of the model between RMs 140 and 160 , which includes the 18.3-mile white sturgeon critical habitat, where the KTOI is assessing the feasibility of a Kootenai River habitat restoration project.

\section{Description of Study Reach}

The Kootenai River originates in British Columbia, Canada, and flows southward into Montana. Downstream of Libby Dam, the river flows westward through Montana and Idaho, eventually turning northward and flowing back into British Columbia (fig. 1). The 66-mile study reach starts at Leonia, Idaho, at RM 171.9, near the Montana and Idaho border and ends at Porthill, Idaho, near the International Border at RM 105.6. The Kootenai River drains an area of approximately 17,600 $\mathrm{mi}^{2}$, and the river flows 448 miles from its headwaters in the Rocky Mountains in British Columbia (elevation of about $11,900 \mathrm{ft}$ ) to the confluence with Kootenay Lake (elevation of about 1,745 ft) (Berenbrock, 2005). The Kootenai River is spelled as Kootenay River in British Columbia. For the purposes of this report, the United States spelling "Kootenai" will be used when referring to the river, and the Canadian spelling "Kootenay" will be used when referring to the lake. Backwater conditions extend upstream of Kootenay Lake into the study reach. Previous model simulations show that for a number of combinations of discharge and downstream water-surface elevation the transition between backwater and free-flowing water remains between about RMs 153 and 156, while observed data indicate the transition extends from about RM 152 to RM 157 (Berenbrock, 2005).

\section{Geomorphic Reaches and Channel Morphology}

Snyder and Minshall (1996) defined three geomorphic reaches in the study area: a canyon reach, a braided reach, and a meander reach (Snyder and Minshall, 1996; Berenbrock, 2005; U.S. Fish and Wildlife Service, 2006). A fourth geomorphic reach can be defined as a straight reach that forms the transition between the braided and meander reaches (Tetra Tech, Inc., 2003; Barton and others, 2005).

The canyon reach extends from Kootenai Falls (RM 193.9) to RM 159.7 below the confluence with the Moyie River and consists of a fairly straight single channel with five sharp bends and is incised into bedrock (figs. 1 and $\underline{2 A}$ ). When discharge is $30,000 \mathrm{ft}^{3} / \mathrm{s}$, the average water depth in the canyon reach is about $16 \mathrm{ft}$ (Berenbrock, 2006).

The braided reach begins below the canyon reach at RM 159.7, where the valley begins to widen, and extends to RM 152.8 where the channel is constricted by bedrock and levees near the U.S. Highway 95 bridge at Bonners Ferry. This reach is primarily a multi-threaded channel, with about $2 \mathrm{mi}$ as a single-threaded channel (figs. 1, $\underline{2 B}$ and $\underline{2 C}$ ). The channel has many gravel bars, sloughs, and islands, and the bed is composed primarily of gravels and cobbles. Many of the side sloughs are dry during periods of low streamflow. Scour pools form at two locations in the upper part of the reach near RMs 157.6 and 159 where bedrock crops out along the river and water depths in the pools can exceed $50 \mathrm{ft}$; here bedrock rubble is strewn on the riverbed. When discharge is 30,000 $\mathrm{ft}^{3} / \mathrm{s}$, the average water depth in the braided reach is about 10 $\mathrm{ft}$, which is typically less than depths in the canyon, straight, and meander reaches (Barton and others, 2009).

Forming the transition between the braided and meander reaches is a short straight reach between RMs 151.9 and 152.8 (fig. 2C). Here, the river substrate consists of gravel, sand, and bedrock. This bedrock crops out at several small areas along the right bank. Ambush Rock near RM 152 is a large outcrop along the left bank at the downstream end of this reach and is collocated with a 75-ft-deep scour hole in the channel. The channel is single threaded except the upstream half of the reach during low streamflow when gravel bars are exposed. When discharge is $30,000 \mathrm{ft}^{3} / \mathrm{s}$ the average depth in the straight reach is about $13 \mathrm{ft}$ (Barton and others, 2009). 


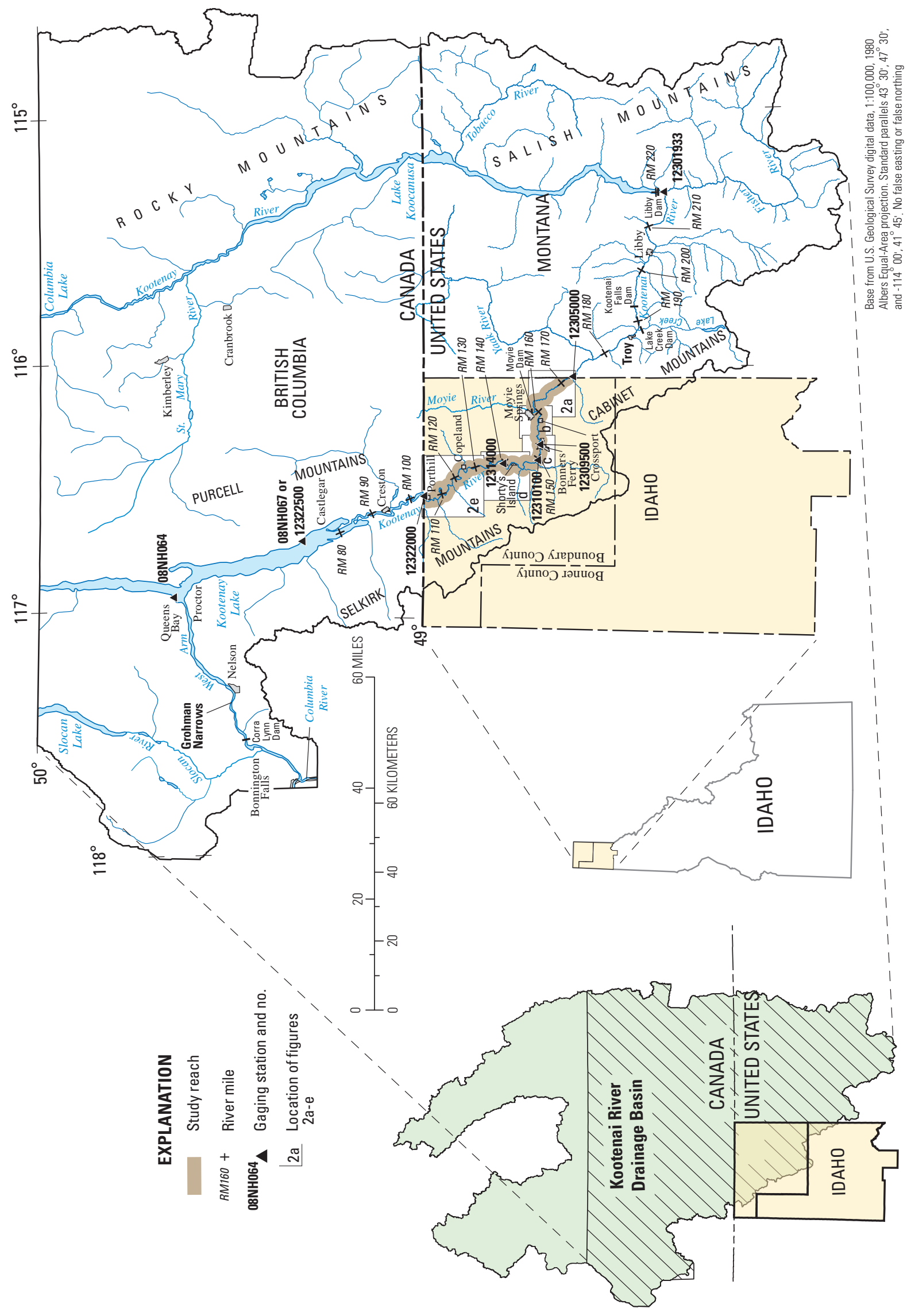

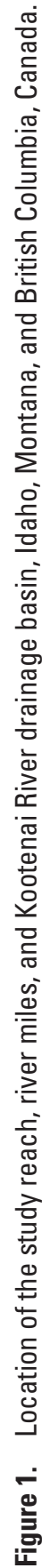




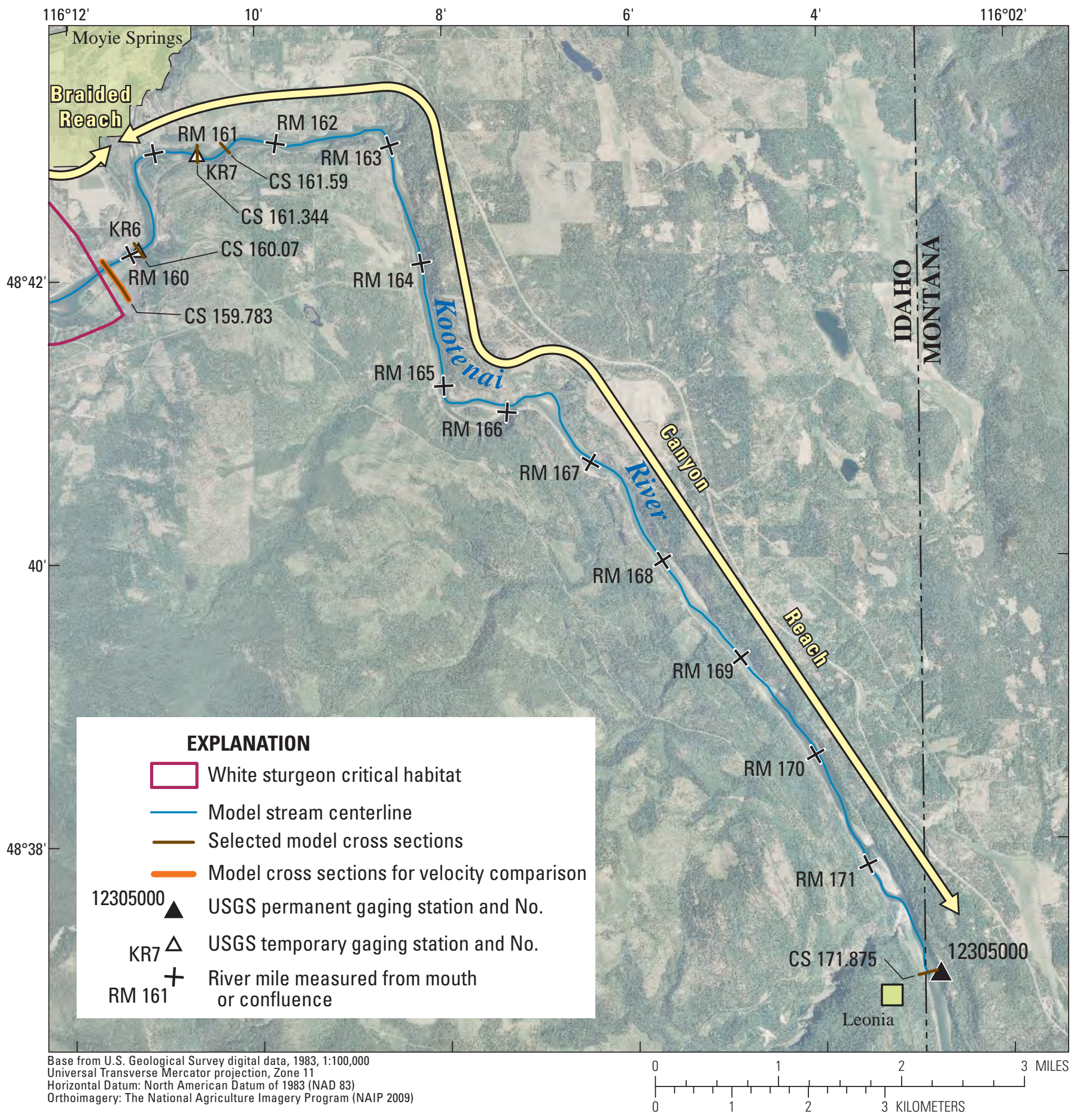

\section{A. River miles (RMs) 160 to 171}

Figure 2. Locations of river miles and selected cross sections on the Kootenai River, Idaho. $A$, river miles (RMs) 160 to 171. $B$, RMs 155 to 162. C, RMs 147 to 155 . D, RMs 132 to 147. E, RMs 105 to 132. 


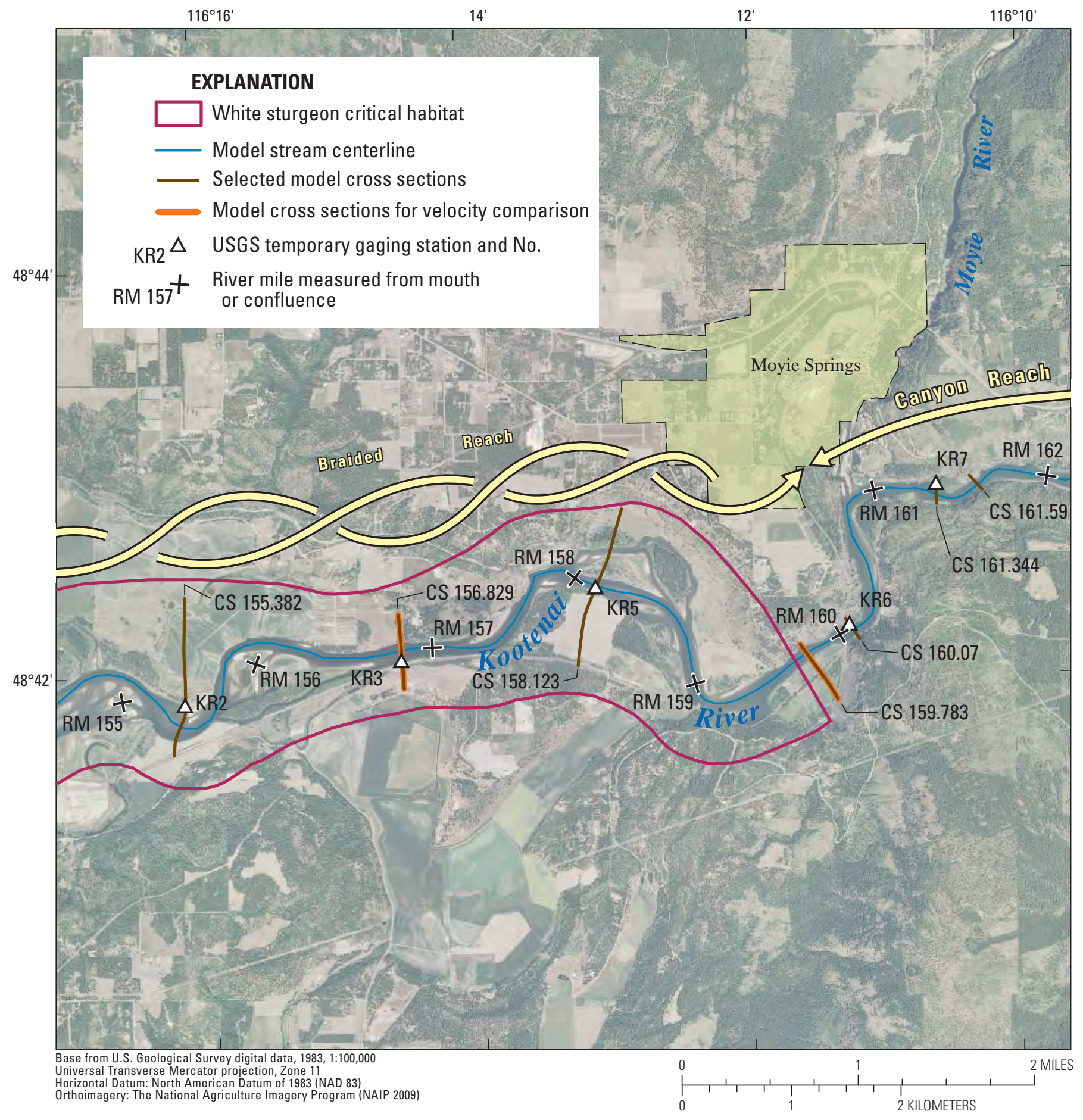

\section{B. River miles (RMs) 155 to 162}

Figure 2.-Continued 


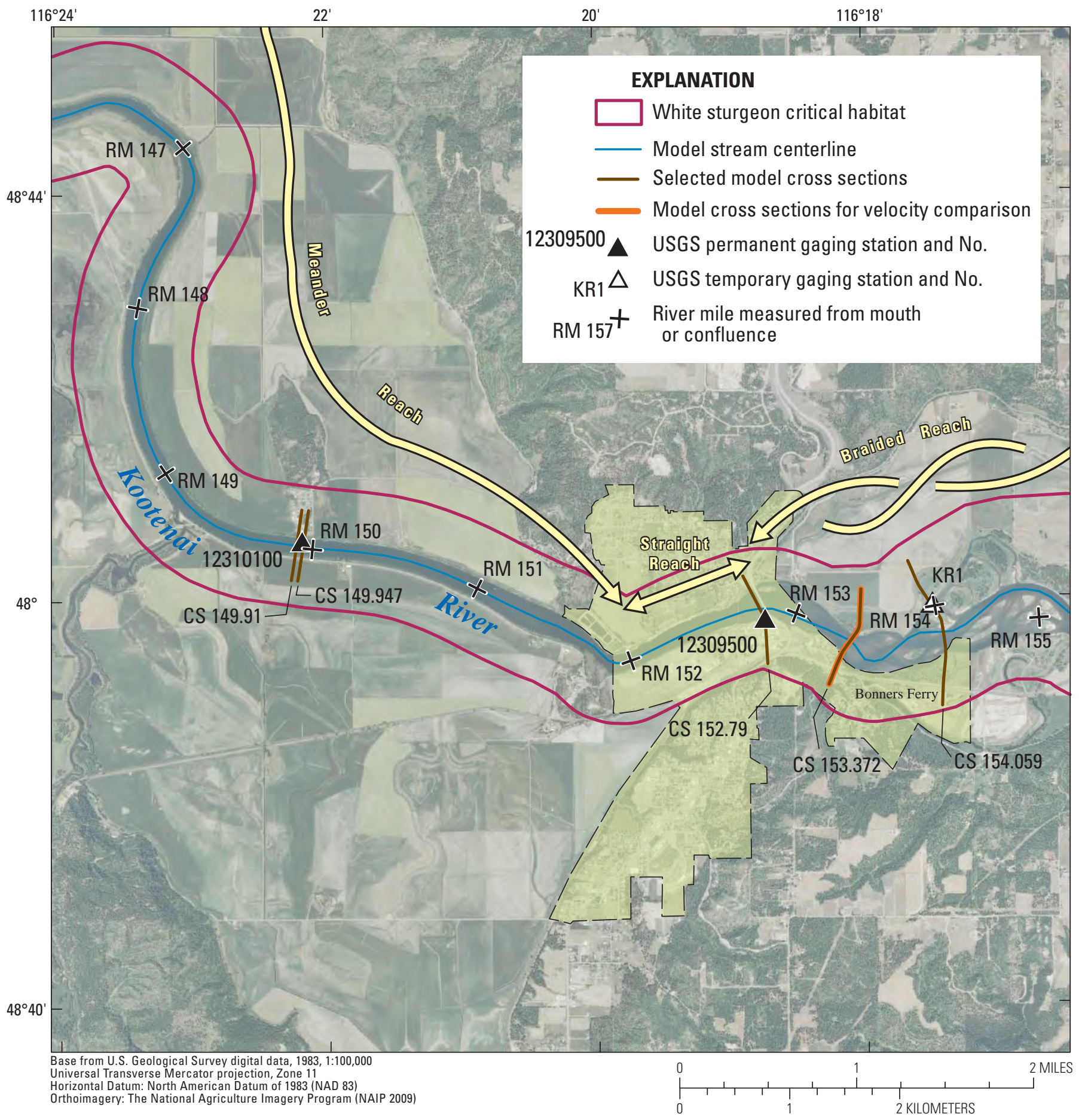

\section{River miles (RMs) 147 to 155}

Figure 2.-Continued 


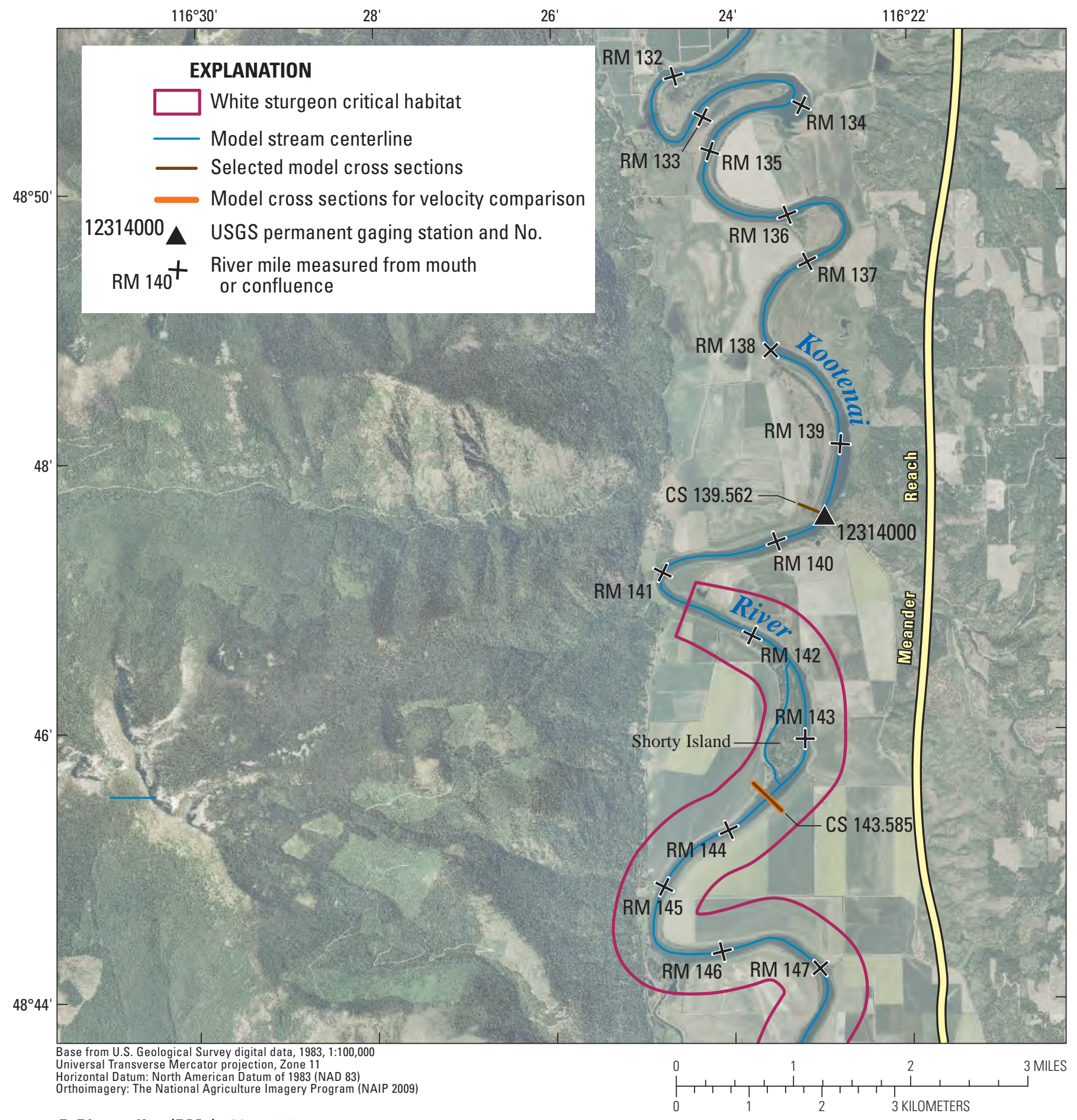

\section{River miles (RMs) 132 to 147}

Figure 2.-Continued 


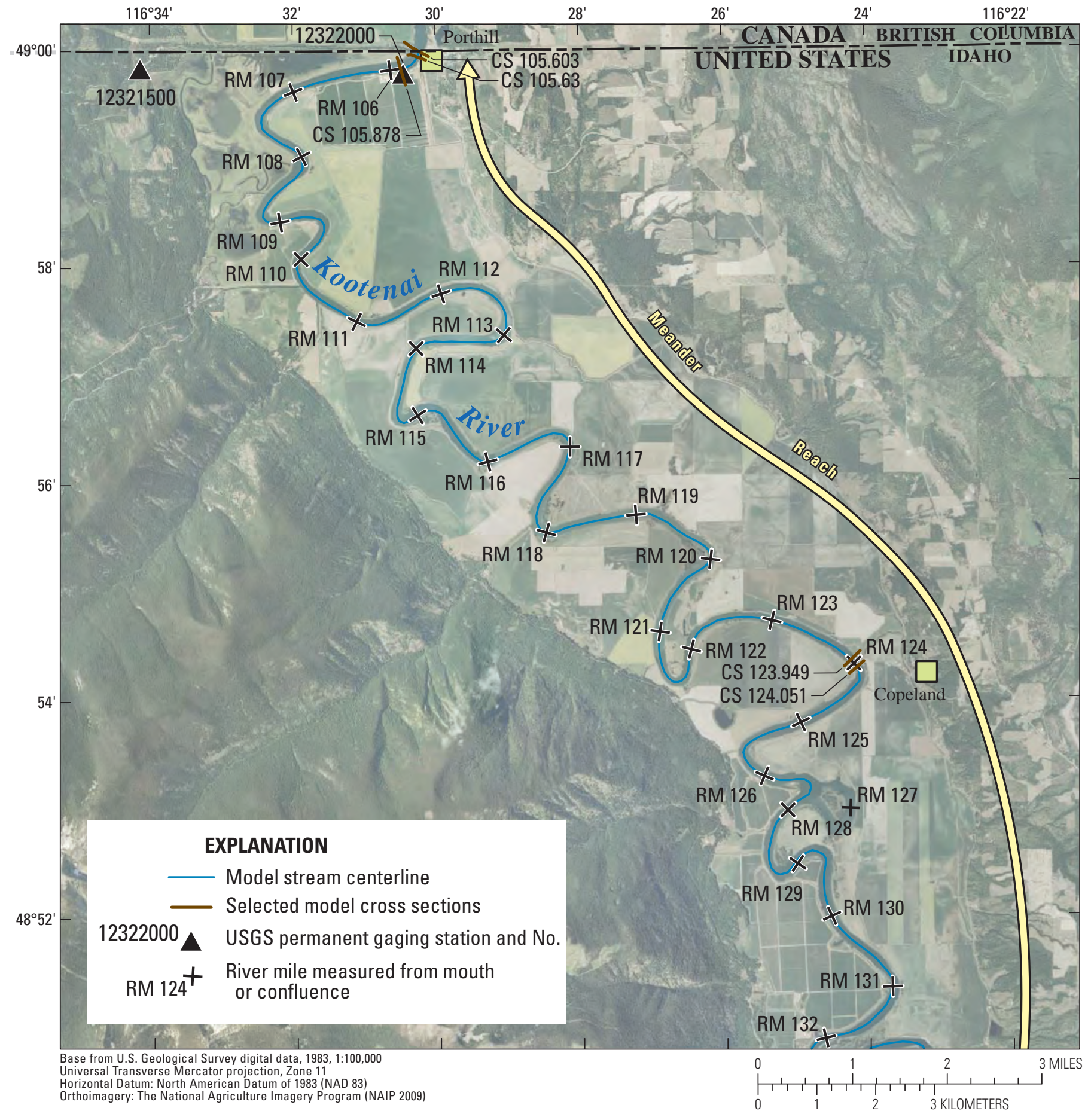

\section{E. River miles (RMs) 105 to 132}

Figure 2-Continued. 
The meander reach is located downstream of the straight reach and extends downstream to Kootenay Lake (RM 77) (figs. 1, 2C, $\underline{2 D}$, and $\underline{2 E}$ ). The meander reach is composed of a single channel with gentle meanders, and also includes an approximately 1-mi-long side channel around the western side of Shorty Island (fig. $2 D$ ). This side channel is shallower and narrower than the main channel on the eastern side of the island. The meander reach is primarily a sand riverbed entrenched in the lacustrine clay valley. This sand forms a mobile streambed consisting mainly of dune bedforms with amplitudes that sometimes are greater than $3 \mathrm{ft}$ (Barton and others, 2009). Lacustrine clay-silt generally forms steep steps and flat-lying shelves mostly in meander bends. At the base of clay steps is clay rubble with the appearance of gravel and cobble. At a few locations there are bedrock outcrops into the channel and along the riverbank with rock rubble on the riverbed. Several small patches of gravel are in lag deposits left behind after the finer material has been transported downstream. Discontinuous lenses of gravel lag deposits are buried by several feet of sand (Barton and others, 2010b). Rip-rap in select locations forms armoring consisting of shot rock, boulders, and cobbles placed on dikes. The meander reach is deeper than the canyon, braided, and straight reaches. When discharge is $30,000 \mathrm{ft}^{3} / \mathrm{s}$ the average depth in the upper meander reach where sturgeon spawn is about $23 \mathrm{ft}$ (Barton and others, 2004; 2009).

\section{White Sturgeon Critical Habitat}

The Kootenai River white sturgeon population is naturally landlocked, locally adapted, and has been isolated since the last glaciations approximately 10,000 years ago. The Kootenai sturgeon was listed as endangered under the Endangered Species Act in 1994. There has been a welldocumented decline in Kootenai sturgeon recruitment over the past 50 years (Partridge, 1983; U.S. Fish and Wildlife Service, 1999; Paragamian and others, 2005). No significant recruitment of young sturgeon has been observed since the early 1970s and consistent annual recruitment has not been observed since the 1950s (U.S. Fish and Wildlife Service, 1999; Paragamian and others, 2005). A recent population assessment concluded that the wild population was between 800 and 1,000 adults with the population declining by approximately 4 percent a year (Ray Beamesderfer, Cramer and Assoc., written commun., 2009). At this rate there will be no remaining wild population by approximately 2080, although functional extinction could occur well before that time.

Kootenai white sturgeon typically spawn in the meander reach near Bonners Ferry, Idaho, between RMs 141.6 and 149.1. A map of spawning events per unit of monitoring effort,
1994-2001 (fig. 3), shows that the sturgeon spawned in the meander reach between RMs 141.8 and 149.3 (figs. 2C and $\underline{2 D}$ ), with a few events observed in the straight reach between RMs 152.1 and 152.3 (fig. 2C) (Barton and others, 2009). Spawning event per unit effort (SEPUE) is the number of times fertilized eggs were detected on an egg mat resting on the riverbed at a sampling site divided by the time the mat was deployed, where egg mats were retrieved, examined, and replaced every 24 to 48 hours (Barton and others, 2009). A series of research investigations determined that sturgeon were spawning over unsuitable incubation and rearing habitat (sand) in the meander reach, and that the survival of eggs and larvae was negligible (Paragamian and others, 2002). Sedimentation has been presented as a likely source of mortality for white sturgeon embryos (Kock and others, 2006). Currently, less than 30 percent of tagged sturgeon spawners swim upstream into the braided reach where there is more suitable gravel substrate for egg incubation, only to briefly inhabit the lowermost part of the reach, before swimming back downstream to the meander or straight reach to spawn (Pete Rust, Idaho Department of Fish and Game, oral commun., 2008).

The U.S. Fish and Wildlife Service updated the 2000 Biological Opinion (BiOp; U.S. Fish and Wildlife Service, 2000; 2006; 2008) due to litigation over the $2000 \mathrm{BiOp}$ and the designation of critical habitat for Kootenai sturgeon in 2001. In a 2008 final ruling (73 FR 39505), a small portion of the Kootenai River from RM 141.4 to RM 159.7 was designated as white sturgeon critical habitat (figs. 1 and 2) (U.S. Fish and Wildlife Service, 2006; 2008). The BiOp specifies a depth and velocity criteria for a sub-reach of the critical habitat, between RMs 152 and 157, that includes the straight reach and lower three-fifths of the braided reach, and is discussed in detail in Barton and others (2010a). The depth criterion was established to ensure adequate depth for white sturgeon to swim upstream of the sandy meander reach to the braided reach where gravel and cobble substrate conditions are favorable for the incubation of sturgeon eggs. The velocity criterion is intended to increase the likelihood of white sturgeon recruitment. Higher velocities are thought to reduce the ability of other fish species to prey on sturgeon eggs and aid egg incubation and downstream dispersal of sturgeon during early life stages.

Multidimensional modeling of the spawning habitat (RMs 141.9 to 152.8; Barton and others, 2005) and additional extended multidimensional modeling (RMs 138.1 to 157.8; Barton and others, 2009) have been used to simulate streamflow conditions and sediment mobility in relation to white sturgeon spawning habitat, and to link stream depth and velocities to biological data (Barton and others, 2009). 


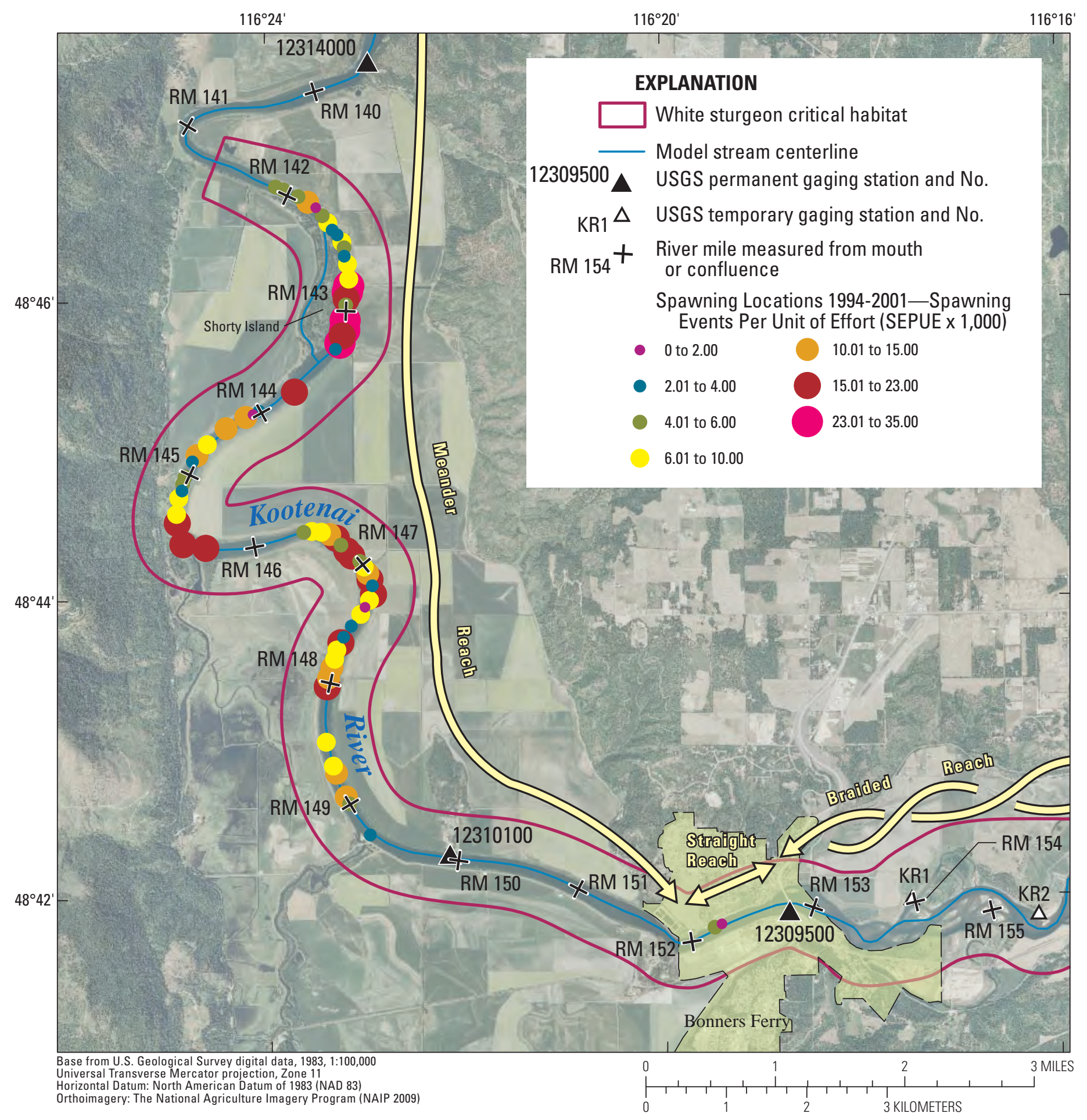

Figure 3. Location and number of white sturgeon spawning events per unit of monitoring effort on the Kootenai River near Bonners Ferry, Idaho, 1994-2001. Spawning event per unit effort (SEPUE) is the number of times fertilized eggs were detected on an egg mat resting on the riverbed at a sampling site divided by the time the mat was deployed. Adapted from Barton and others, 2009. 


\section{Streamflow-Gaging Stations}

In the model reach, stage and discharge were measured at 15-minute intervals on the Kootenai River at three USGS permanent streamflow-gaging stations: Kootenai River at Leonia, Idaho (USGS streamflow-gaging station 12305000), Kootenai River at Tribal Hatchery near Bonners Ferry, Idaho (12310100), and Kootenai River at Porthill, Idaho (12322000) (table 1; figs. $2 A, \underline{2 C}$, and $\underline{2 E}$ ). Two additional USGS permanent gaging stations recorded stage only at 15-minute intervals: the Kootenai River at Bonners Ferry, Idaho (12309500) and the Kootenai River at Klockmann Ranch near Bonners Ferry, Idaho (12314000) (table 1; figs. 2C and 2D).

The Leonia (12305000) and Porthill (12322000) gaging stations were located at the upstream and downstream model boundaries, respectively. Between 2006 and 2008, the USGS installed seven temporary stage and water-temperature gaging stations in the braided reach between RMs 154.1 and 159.6 and in the downstream part of the canyon reach at RM 161.2 (table 1; figs. 2A and 2E). However, one gaging station (KR4) was discontinued in 2007 and was not used in this modeling effort. These temporary stage-gaging stations were each equipped with a 30-pounds-per-square-inch transducer and recorded at 15-minute intervals (table 1).

The Kootenai River at Porthill (12322000) is an international gaging station and the discharge value reported represents the total amount passing over the border into Canada. To determine the discharge in the Kootenai River upstream of the border, the discharge from the Boundary Creek near Porthill, Idaho (12321500) must be subtracted from the discharge reported at the Porthill gaging station.

Table 1. U.S. Geological Survey streamflow-gaging stations on the Kootenai River, Idaho.

[Gaging station locations are shown in figures 1 and 2. Abbreviations USGS, U.S. Geological Survey; RKM, river kilometer; RM, river mile; Data parameters: S, stage; Q, discharge; V, velocity; T, temperature]

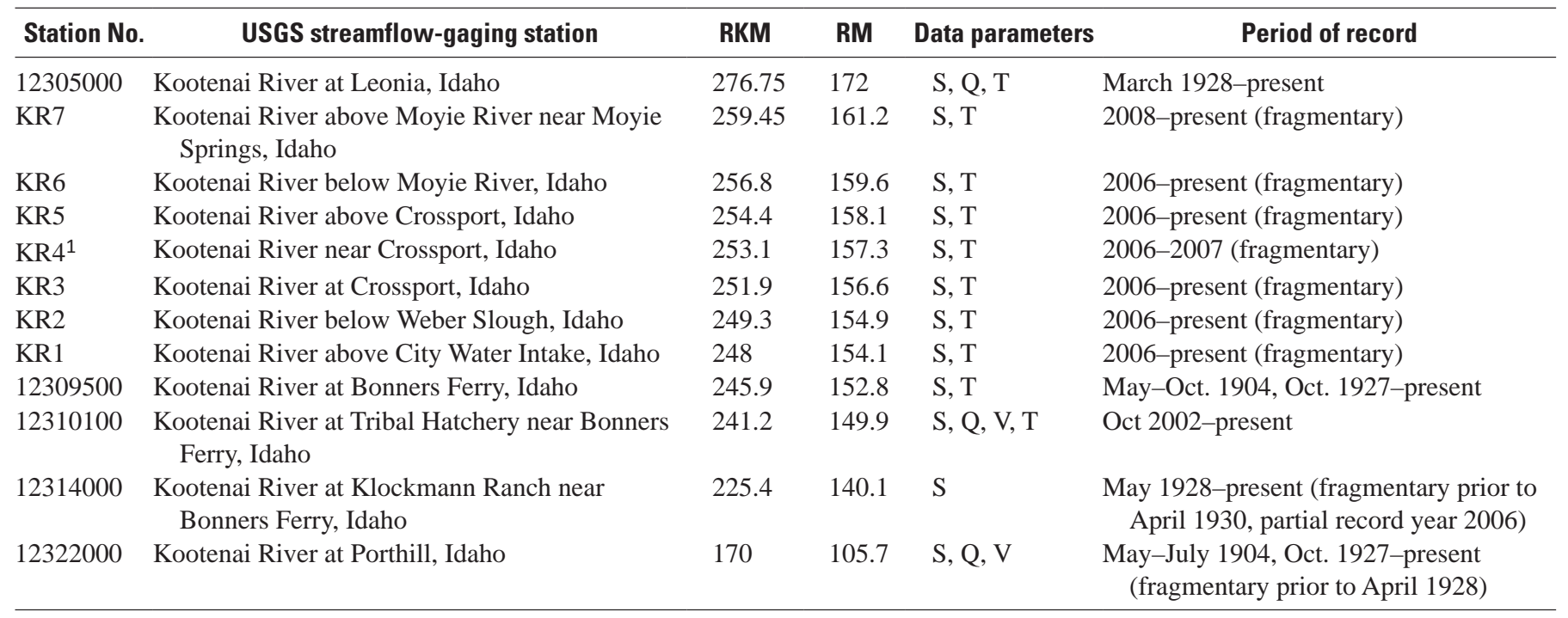

\footnotetext{
${ }^{1}$ Gaging station was discontinued in 2007 and not used in this modeling effort or shown in figures.
} 


\section{Model Development}

The Hydrologic Engineering Center's River Analysis System (HEC-RAS) computer model, version 4.1 (Brunner, 2010a and 2010b; Warner and others, 2010) was used to construct a 1-D surface-water, hydraulic model of the Kootenai River from the Leonia gaging station (12305000) to the Porthill gaging station (12322000). The steady flow component of HEC-RAS was used to simulate 1-D, gradually varied, steady flow in open channels with fixed boundaries. The model solves the 1-D energy equation and accounts for energy losses due to friction (Manning's equation), contraction, and expansion. Energy was assumed to be uniform across a given cross section; however, this assumption can be inaccurate where streamflow is not parallel to the main channel or where the streamflow is highly three-dimensional. The model also assumed that streamflow was unobstructed, or that there were no debris or obstacles in the channel or floodplain. The model was built based on a previous USGS model (Berenbrock, 2005) and developed in conjunction with modeling efforts by River Design Group, Inc., which is under contract with the KTOI (River Design Group, Inc., 2009). The locations and extent of cross sections between RMs 140 and 160 were developed for this model as specified by River Design Group, Inc. to enable a direct comparison of 1-D modeling efforts between the USGS and River Design Group, Inc. (Sean Welch, River Design Group, Inc., oral commun., 2009).

\section{Bathymetry, Streambank and Floodplain Topography}

River channel bathymetry and the nearby floodplain topography were defined by a combination of bathymetric measurements made by the USGS from 2002 to 2009 and Light Detection and Ranging (LIDAR) measurements made in 2005. All bathymetric mapping by the USGS was collected using real-time kinematic (RTK) global positioning system (GPS) equipment with survey-grade echo sounders. Vertical datum for the bathymetric and LIDAR measurements was the North American Vertical Datum of 1988 (NAVD 88). Horizontal coordinate information for the bathymetric and LIDAR measurements was referenced to the North American Datum of 1983 (NAD 83), Universal Transverse MercatorZone 11, in feet. Only the bathymetric data and LIDAR data used in the updated 1-D model are discussed here; discussion of the development of the original model can be found in Berenbrock (2005).

During 2002 and 2003 the USGS measured water depth with a single-beam echo sounder (Innerspace Technology, Inc., Model 448). Cross-section spacing between RMs 141 and 152 ranged from less than $30 \mathrm{ft}$ to about $160 \mathrm{ft}$ (Barton and others, 2004; 2005; 2009). During 2004 and 2005 the USGS also measured water depth with a four-beam echo sounder (Ross Model 875-4 with four channels). Spacing between each of the four sounding transducers was $2.8 \mathrm{~m}$. The 4-beam echo sounder was used to survey a series of longitudinal lines between RMs 147.1 and 152.8 and between RMs 138.1 and 144.2. Longitudinal lines generally were parallel and spaced relatively close together in the straight and meander reaches so that about 80 percent of the river bottom was surveyed. In general, the bathymetry was mapped using the single-beam and four-beam echo sounders to varying degrees of coverage based on the variability of the river bottom. Bathymetry was mapped with greater coverage where river depth was more variable. Where the bottom was relatively uniform, less bathymetric data were needed to characterize the shape of the channel. The 2002, 2003, and 2005 bathymetric and 2005 LIDAR elevation data between RMs 138.1 and 157.8 were mapped to a $10 \times 10$-m grid using a "nearest-neighbor" method described by Barton and others (2005, p. 20).

A LIDAR survey was flown throughout the Kootenai River valley downstream of the canyon reach in Idaho between RMs 105.6 and 159.5 during spring 2005 when discharge was approximately $12,000 \mathrm{ft}^{3} / \mathrm{s}$. A contractor for KTOI surveyed the valley floor, floodplain, and the channel banks down to the edge of the water. The LIDAR survey data were provided to the USGS as a 1-m digital elevation model.

High-resolution bathymetric data were obtained by use of a multibeam echo sounder (MBES) in 2008 and 2009 (Barton and others, 2010b). During 2008 an MBES was used to map the elevation of the Kootenai River channel between RMs 149.5 and 150.0, 145.4 and 146.0, and 141.7 and 143.7. During 2009, an MBES survey was conducted over the entire braided reach and the lower canyon reach, from RM 152.8 to RM 160.7. The MBES system used a flat-array transducer that sends out a 240-kilohertz pulse over a 120-degree swath width and was set to 240 beams and a beam width of 0.75 degrees for these measurements. The MBES is capable of operating in water depths from 1.6 to $197 \mathrm{ft}$. The MBES was coupled to a (1) dynamic motion sensor (DMS-10) with an accuracy of 0.07 degrees, (2) pair of differential GPS antennas that measured heading with an accuracy of 0.25 degrees, (3) realtime kinematic GPS for positioning with a vertical accuracy of $0.13 \mathrm{ft}$, and (4) velocimeter that measured sound velocity at the MBES transducer head with an accuracy of $0.7 \mathrm{ft} / \mathrm{s}$. Data acquisition and processing were accomplished using Odom and Hypack software systems. A 1-m digital elevation model was created from the raw MBES data; each square meter had multiple MBES soundings of usually 10 or more. The MBES mapped approximately 85 percent of the entire river bottom. For the 2009 survey in the braided reach, the mean difference between GPS- and MBES-measured riverbed elevations was $0.07 \mathrm{ft}$ with a standard deviation of $0.3 \mathrm{ft}$.

Overall, the density of bathymetric data varies from one or two orders of magnitude greater in the reach between RMs 138 and 161.4 compared to the rest of the 1-D model reach due to the increased resolution from the MBES and additional single-beam surveys. 


\section{Model Cross Sections}

The 1-D HEC-RAS model developed by Berenbrock (2005) was constructed using 164 cross sections that are presented in Barton and others (2004). The revised model contains 694 cross sections, with the greatest density of these cross sections between RMs 140 and 160 (figs. 4A and $\underline{4 B}$ ). Of the 694 cross sections, 52 in the revised model (located upstream of RM 161.5 and downstream of RM 138) include channel geometry from Berenbrock's (2005) 1-D model. Cross sections downstream of RM 138 were also partially updated by replacing the bank geometry with 2005 LIDAR data. However, LIDAR data were not available for cross sections in the canyon reach upstream of RM 161.5. Between RMs 138 and 161.5, which includes the 18.3-mile Kootenai River white sturgeon critical habitat and braided reach where habitat enhancement projects are being considered (River Design Group, Inc., 2009), there are 642 cross sections in the model containing the updated bathymetric data in the channel and 2005 LIDAR data on the banks and in the floodplain, providing sufficient resolution to design habitat enhancement structures.

The only structure included in the model is the Copeland Bridge near RM 124, as it is the only structure expected to have significant impact on the streamflow (fig. 4A). Bridge geometry and channel geometry for the two adjacent cross sections were taken from the Berenbrock (2005) model; however, the bank geometry was updated to reflect the 2005 LIDAR data.

Downstream flow distances between cross sections were measured along the stream centerline to accurately account for friction losses. These distances differ from the distance that would be computed by subtracting the river mile designators. The distance between cross sections ranges from about $78 \mathrm{ft}$ in the braided reach to as much as about $2.1 \mathrm{mi}$ in the lower meander reach. Cross sections are most densely spaced between RMs 140 and 160, at an average distance of about $175 \mathrm{ft}$ (figs. 4A and $\underline{4 B}$ ). Upstream of RM 161.4 and downstream of RM 138 the cross sections are generally spaced on the order of one-half mile apart (fig. 4A).

Default contraction and expansion coefficients of 0.1 and 0.3 , respectively, corresponding to gradual transitions, were specified for each cross section. Bank points were specified for each cross section corresponding to the approximate horizontal break between channel and bank roughness. Levee points were specified in appropriate cross sections where inundation was not expected in lower floodplain areas unless a high bank was first overtopped. Ineffective areas were specified in several cross sections where small tributaries entering the main stem were represented in the floodplain area of the cross section geometry, such that inundation is apparent in the ineffective area but it is not included in hydraulic computations of the main channel conveyance. Obstructions were specified in several cross sections in the side channel around Shorty Island, where the cross section represented the side of the main channel on the east side of Shorty Island, to account only for streamflow area in the side channel and not double count streamflow area in the main channel. Storage areas were not simulated in this hydraulic model.

Roughness coefficients (Manning's $n$ ) are specified at every cross section to represent the flow resistance. Flow resistance is due to size, gradation, and angularity of streambed particles, channel shape, presence and type of bedforms (dunes, antidunes, ripples, and bars), riparian vegetation, manmade and natural structures, suspended sediment and bedload transport, and channel meandering. In general, flow resistance increases with increasing bed-material size and usually decreases as discharge increases because the bed roughness disrupts the streamflow less as the ratio of the depth to bed-material size increases.

Roughness coefficients established from the previous model calibration (Berenbrock, 2005) were used to interpolate roughness coefficients for the initial model runs in this study. In the Berenbrock (2005) model, the channel Manning's $n$ values ranged from 0.020 to 0.050 for different reaches and different discharges, and the bank Manning's $n$ values were set to 0.060 throughout the study reach. For all cross sections, the roughness values were set to vary with discharge based on model calibration. In general, the specified bank point demarcates the change in roughness between the channel and the bank Manning's $n$ values. The bank roughness represents both the bank and floodplain region of a given cross section. In addition, many of the cross sections in the braided reach with multiple channels separated by wide, often vegetated bars, required additional horizontal variation in $n$ values. In this case, the vegetated bars and islands were given the bank roughness value and side channels were given the channel roughness value. 


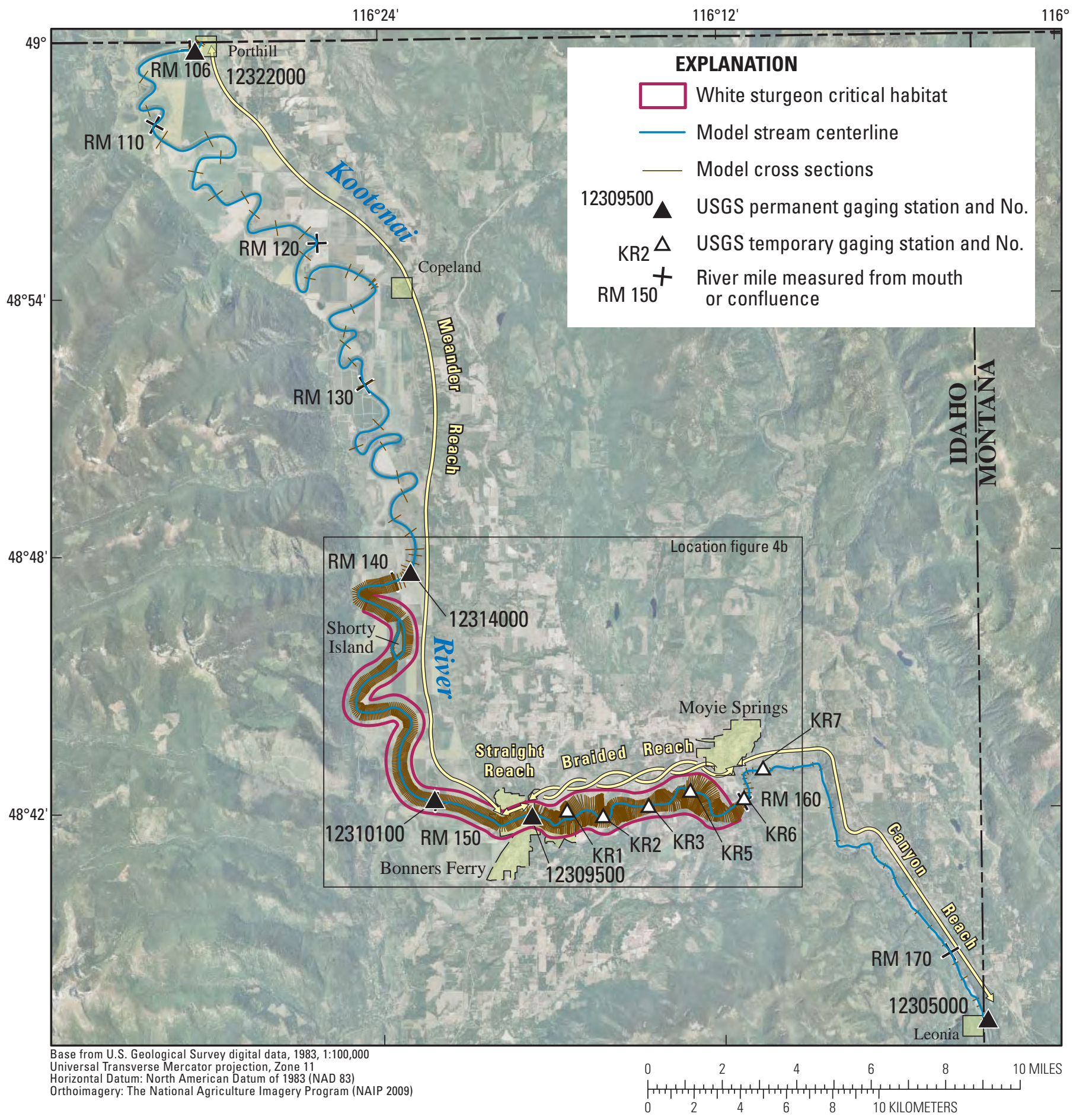

\section{A. River miles (RMs) 172 to 105 (entire study reach)}

Figure 4. Location and extent of cross sections in the study reach, Kootenai River, Idaho. A. Cross sections in the entire study reach. $B$. Detailed view of densely spaced cross sections, river miles 140 to 160. 


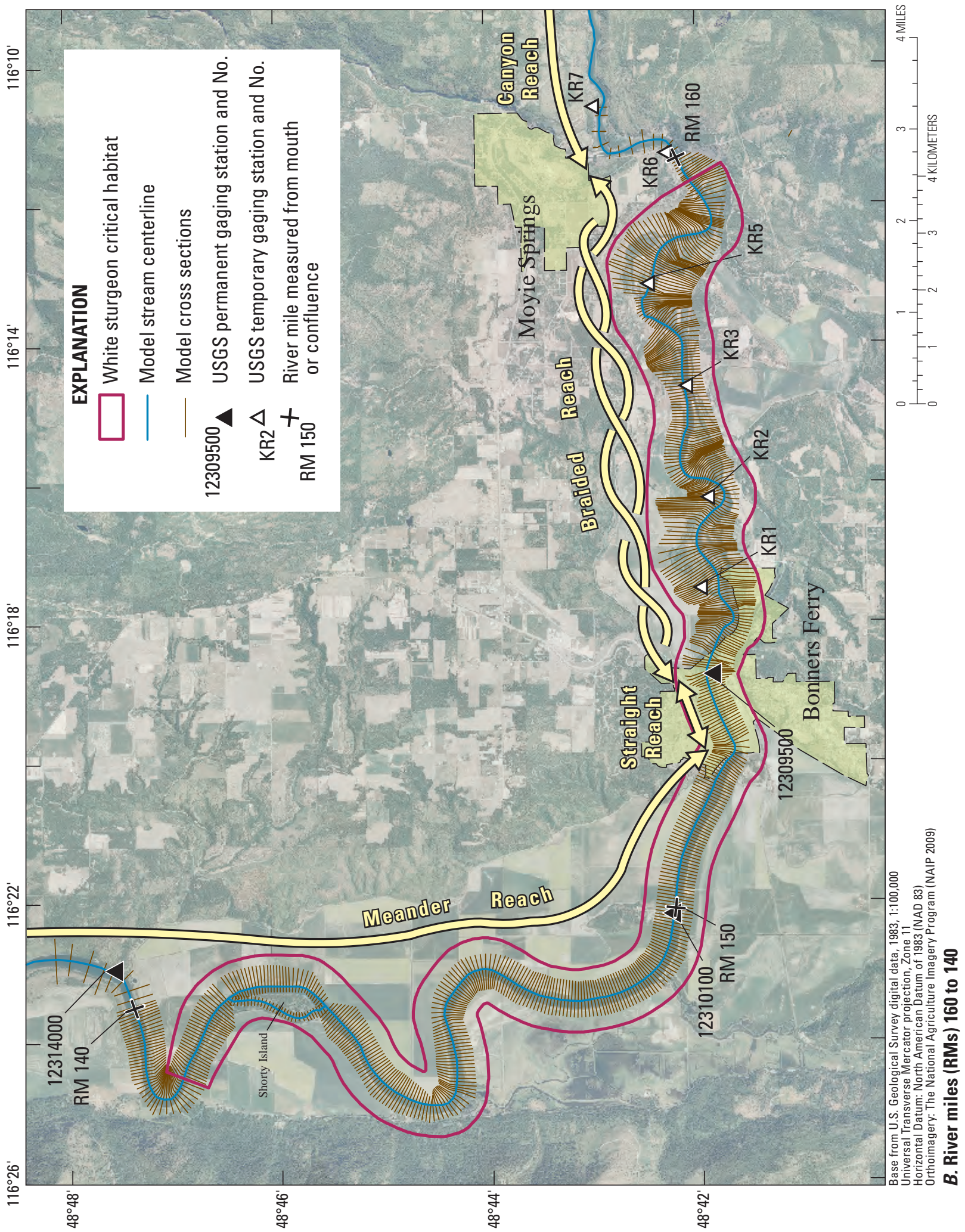

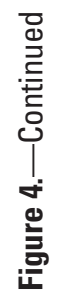




\section{Model Boundary Conditions}

Since the dominant streamflow condition in the Kootenai River is subcritical flow (defined as a Froude number less than one), the model required only discharge data at the upstream boundary (cross section 171.875) and water-surface elevation at the downstream boundary (cross section 105.603). Discharge was also specified at two additional locations to account for large tributary inputs throughout the study reach.

The Kootenai River at Porthill gaging station (12322000) provided water-surface elevations at the downstream model boundary. Discharge at the upstream model boundary was obtained from discharge recorded every 15 minutes at the Kootenai River at Leonia gaging station (12305000). Due to significant increases in discharge throughout the study reach, discharge was also specified at two more locations in the model. From the Above Moyie River (KR7) gaging station downstream to Klockmann Ranch (12314000), discharge in the model was obtained from discharge recorded every 15 minutes at the Tribal Hatchery gaging station (12310100). This is validated because there are no significant contributions of discharge between these two locations. The discharge from Klockmann Ranch (12314000) to Porthill (12322000) was computed from the discharges at the Porthill gaging station (12322000) and the Boundary Creek gaging station (12321500) to determine the discharge in the Kootenai River at the Porthill gaging station rather than the total discharge passing the International Border downstream of the Boundary Creek inflow (the Porthill gaging station reports the total discharge passing the International Border).
The river splits into two separate reaches around Shorty Island. The main channel on the eastern side of the island carries all the discharge during low-flow conditions. For each simulation, discharge at the junction at the upstream end of Shorty Island was allowed to optimize to determine the discharge being routed through each of the reaches around Shorty Island, such that the sum of the discharges from the two reaches was equal to the discharge in the main channel immediately upstream and downstream of the island. The majority of the discharge was routed through the main channel on the eastern side of the island, and at progressively larger events the discharge in the smaller side channel on the western side of Shorty Island increased to a maximum of 14 percent of the total discharge for the highest calibration event simulated.

\section{Model Calibration}

The model was calibrated by comparing measured and simulated water-surface elevations for seven storm events covering a range of discharges (table 2), and adjusting channel roughness coefficients (Manning's $n$ ) to minimize the difference between measured and simulated water-surface elevations. Model calibration was considered adequate for each site and calibration event when the difference was within $\pm 0.15 \mathrm{ft}$ (table 3). Calibration reaches were defined between each gaging station in the study reach, and adjustments to the channel roughness values were made equally to all cross sections within each calibration reach.

Table 2. Model boundary conditions for calibration events, Kootenai River, Idaho.

[Gaging station locations are shown in figures 2 and $\underline{4}$; Gaging station descriptions are shown in table 1 . Abbreviations $\mathrm{ft}$, foot; $\mathrm{ft}^{3} / \mathrm{s}$, cubic foot per second]

\begin{tabular}{ccccc}
\hline \multirow{2}{*}{$\begin{array}{c}\text { Calibration } \\
\text { event }\end{array}$} & $\begin{array}{c}\text { Leonia (12305000) } \\
\text { to Above } \\
\text { Moyie River (KR7) }\end{array}$ & $\begin{array}{c}\text { Discharge in reach (ft } \mathbf{3} / \mathbf{s}) \\
\text { to Klockmann Ranch } \\
(\mathbf{1 2 3 1 4 0 0 0 )}\end{array}$ & $\begin{array}{c}\text { Klockmann Ranch } \\
\mathbf{( 1 2 3 1 4 0 0 0 )} \\
\text { Porthill (12322000) }\end{array}$ & $\begin{array}{c}\text { Downstream } \\
\text { water-surface } \\
\text { elevation (ft) at } \\
\text { Porthill (12322000) }\end{array}$ \\
\hline $03-17-10$ & 4,833 & 5,132 & 5,522 & $1,745.18$ \\
$08-27-07$ & 15,642 & 16,314 & 17,172 & $1,749.15$ \\
$05-16-07$ & 21,888 & 27,138 & 28,532 & $1,754.19$ \\
$06-18-08$ & 32,730 & 36,853 & 37,964 & $1,756.22$ \\
$06-03-08$ & 36,434 & 42,246 & 46,114 & $1,757.86$ \\
$06-21-06$ & 54,892 & 56,892 & 61,001 & $1,760.97$ \\
$06-20-06$ & 58,642 & 60,012 & 63,049 & $1,761.12$ \\
\hline
\end{tabular}


Table 3. Measured and simulated water-surface elevations for calibration events, Kootenai River, Idaho.

[Gaging station locations and cross sections are shown in figures 2 and $\underline{4}$. Gaging station descriptions are shown in table 1 . Model boundary conditions for calibration events are shown in table 2. Abbreviations CS, cross section; -, no data]

\begin{tabular}{|c|c|c|c|c|c|c|c|c|c|}
\hline \multirow{3}{*}{$\begin{array}{l}\text { Calibration } \\
\text { event }\end{array}$} & \multicolumn{9}{|c|}{ Water-surface elevation (in feet) } \\
\hline & \multicolumn{3}{|c|}{$\begin{array}{l}\text { Leonia (12305000) } \\
\text { (CS 171.875) }\end{array}$} & \multicolumn{3}{|c|}{$\begin{array}{l}\text { Above Moyie River (KR7) } \\
\text { (CS 161.344) }\end{array}$} & \multicolumn{3}{|c|}{$\begin{array}{l}\text { Below Moyie River (KR6) } \\
\text { (CS 160.07) }\end{array}$} \\
\hline & Measured & Simulated & Difference & Measured & Simulated & Difference & Measured & Simulated & Difference \\
\hline $03-17-10$ & $1,804.73$ & $1,804.73$ & 0.00 & - & $1,774.27$ & - & - & $1,771.13$ & - \\
\hline $08-27-07$ & 1,809.24 & $1,809.24$ & 0.00 & - & $1,778.81$ & - & $1,774.97$ & $1,774.94$ & -0.03 \\
\hline $05-16-07$ & 1,811.32 & $1,811.28$ & -0.04 & - & 1,781.33 & - & $1,777.12$ & $1,777.04$ & -0.08 \\
\hline 06-18-08 & $1,814.54$ & $1,814.63$ & 0.09 & 1,783.22 & $1,783.17$ & -0.05 & $1,778.51$ & $1,778.56$ & 0.05 \\
\hline 06-03-08 & $1,815.47$ & $1,815.43$ & -0.04 & $1,784.30$ & $1,784.22$ & -0.08 & $1,779.61$ & $1,779.59$ & -0.02 \\
\hline $06-21-06$ & 1,818.93 & 1,818.92 & -0.01 & - & $1,786.75$ & - & - & 1,781.86 & - \\
\hline 06-20-06 & $1,819.53$ & $1,819.56$ & 0.03 & - & 1,787.27 & - & - & 1,782.33 & - \\
\hline \multirow{2}{*}{$\begin{array}{l}\text { Calibration } \\
\text { event }\end{array}$} & \multicolumn{3}{|c|}{$\begin{array}{l}\text { Above Crossport (KR5) } \\
\text { (CS 158.123) }\end{array}$} & \multicolumn{3}{|c|}{$\begin{array}{l}\text { Crossport (KR3) } \\
\text { (CS 156.829) }\end{array}$} & \multicolumn{3}{|c|}{$\begin{array}{l}\text { Below Weber Slough (KR2) } \\
\text { (CS 155.382) }\end{array}$} \\
\hline & Measured & Simulated & Difference & Measured & Simulated & Difference & Measured & Simulated & Difference \\
\hline $03-17-10$ & - & $1,764.65$ & - & - & $1,760.87$ & - & - & $1,756.96$ & - \\
\hline $08-27-07$ & $1,768.21$ & $1,768.26$ & 0.05 & $1,764.07$ & $1,764.03$ & -0.04 & $1,759.10$ & $1,759.13$ & 0.03 \\
\hline $05-16-07$ & $1,770.76$ & $1,770.82$ & 0.06 & $1,766.32$ & $1,766.34$ & 0.02 & - & $1,761.75$ & - \\
\hline 06-18-08 & $1,773.15$ & 1,773.18 & 0.03 & $1,768.53$ & $1,768.48$ & -0.05 & $1,764.31$ & 1,764.39 & 0.08 \\
\hline 06-03-08 & $1,774.33$ & $1,774.24$ & -0.09 & $1,769.75$ & $1,769.75$ & 0.00 & $1,766.26$ & $1,766.33$ & 0.07 \\
\hline 06-21-06 & $1,776.70$ & $1,776.69$ & -0.01 & $1,772.89$ & $1,772.96$ & 0.07 & $1,771.25$ & $1,771.16$ & -0.09 \\
\hline $06-20-06$ & $1,777.26$ & $1,777.22$ & -0.04 & $1,773.42$ & $1,773.46$ & 0.04 & $1,771.77$ & $1,771.71$ & -0.06 \\
\hline \multirow{2}{*}{$\begin{array}{l}\text { Calibration } \\
\text { event }\end{array}$} & \multicolumn{3}{|c|}{$\begin{array}{l}\text { Above City Water Intake (KR1) } \\
\text { (CS 154.059) }\end{array}$} & \multicolumn{3}{|c|}{$\begin{array}{l}\text { Bonners Ferry (12309500) } \\
\text { (CS 152.79) }\end{array}$} & \multicolumn{3}{|c|}{$\begin{array}{c}\text { Tribal Hatchery (12310100) } \\
\text { (Average of CS } 149.947 \text { and 149.91) }\end{array}$} \\
\hline & Measured & Simulated & Difference & Measured & Simulated & Difference & Measured & Simulated & Difference \\
\hline $03-17-10$ & - & $1,752.82$ & - & - & $1,747.84$ & - & $1,746.26$ & $1,746.18$ & -0.08 \\
\hline $08-27-07$ & $1,756.21$ & $1,756.24$ & 0.03 & $1,753.70$ & 1,753.69 & -0.01 & $1,752.95$ & $1,752.93$ & -0.02 \\
\hline $05-16-07$ & - & $1,760.50$ & - & $1,759.56$ & 1,759.59 & 0.03 & $1,758.93$ & $1,758.99$ & 0.06 \\
\hline 06-18-08 & $1,763.75$ & $1,763.74$ & -0.01 & $1,762.90$ & $1,762.92$ & 0.02 & $1,762.21$ & $1,762.23$ & 0.01 \\
\hline 06-03-08 & $1,765.94$ & $1,765.91$ & -0.03 & $1,764.99$ & $1,765.03$ & 0.04 & $1,764.33$ & $1,764.34$ & 0.00 \\
\hline 06-21-06 & $1,770.54$ & $1,770.51$ & -0.03 & $1,769.74$ & 1,769.72 & -0.02 & $1,769.00$ & $1,768.97$ & -0.03 \\
\hline $06-20-06$ & $1,771.09$ & $1,771.08$ & -0.01 & $1,770.20$ & $1,770.28$ & 0.08 & $1,769.44$ & $1,769.48$ & 0.03 \\
\hline \multirow[t]{2}{*}{$\begin{array}{l}\text { Calibration } \\
\text { event }\end{array}$} & \multicolumn{3}{|c|}{$\begin{array}{l}\text { Klockmann Ranch (12314000) } \\
\text { (CS 139.562) }\end{array}$} & $\begin{array}{c}\text { Porthill } \\
\text { (12322000) } \\
\text { (CS 105.603) }\end{array}$ & & & & & \\
\hline & Measured & Simulated & Difference & Measured & & & & & \\
\hline $03-17-10$ & - & $1,745.70$ & - & $1,745.18$ & & & & & \\
\hline 08-27-07 & $1,751.54$ & $1,751.51$ & -0.03 & $1,749.15$ & & & & & \\
\hline $05-16-07$ & $1,757.51$ & $1,757.45$ & -0.06 & $1,754.19$ & & & & & \\
\hline 06-18-08 & $1,760.58$ & $1,760.53$ & -0.05 & $1,756.22$ & & & & & \\
\hline 06-03-08 & $1,762.68$ & $1,762.69$ & 0.01 & $1,757.86$ & & & & & \\
\hline 06-21-06 & - & $1,767.08$ & - & $1,760.97$ & & & & & \\
\hline 06-20-06 & - & $1,767.47$ & - & $1,761.12$ & & & & & \\
\hline
\end{tabular}


The selection of historical streamflow events for model calibration was based on three criteria: (1) stage and discharge values were limited to the Libby Dam era; (2) events should be distributed between low discharge (less than $6,000 \mathrm{ft}^{3} / \mathrm{s}$ ) and the Libby Dam era peak instantaneous discharge $(64,300$ $\mathrm{ft}^{3} / \mathrm{s}$, June 19, 2006, at the Tribal Hatchery gaging station 12310100) so the model could be adequately calibrated over the range of likely discharges; and, (3) because HEC-RAS was used as a steady-state model, calibration conditions were selected that represented periods of relatively constant water-surface elevation and discharge. Since the influence of backwater conditions from Lake Kootenay in the study varies over seasons and storm events (Berenbrock, 2005), efforts were made to choose calibration events that represented average conditions at the downstream model boundary, such that for a given calibration event, the water-surface elevation at Porthill (12322000) was approximately a median value for the range of historical conditions at that discharge (fig. 5).

Seven calibration events were chosen to meet these criteria (table 2; fig. 5). To determine model boundary conditions for the calibration and verification events, the daily mean of the instantaneous values of discharge and watersurface elevation reported at all gaging stations was used. However, for the largest calibration events, a shorter time period was used (down to 6 hours at the largest event) since the discharge changed considerably over a 24-hour period.

Six of the calibration events were based solely on gaging station data. However, the lowest calibration event in the model was primarily based on a synoptic stage survey conducted on March 17, 2010, between 0900 and 1500 hours (fig. 6). Water-surface elevations for the synoptic stage survey were measured using RTK-GPS throughout the reach and these measurements were accurate to within $0.1 \mathrm{ft}$.

Calibrated water-surface elevations were within \pm 0.10 $\mathrm{ft}$ of the measured values at gaging stations (table 3). Data for the low-flow calibration event were collected during the synoptic stage survey on March 17, 2010. Water-surface elevations measured at 14 surveyed locations and 3 gaging stations were compared to simulated water-surface elevations (fig. 6). Calibration for the low-flow event was conducted using the same calibration reaches as the other six calibration events. However, in many cases multiple water-surface elevations were measured within one calibration reach. The calibration goal was to minimize the error for all pairs of simulated and measured elevations within one calibration reach by using a single Manning's $n$ value for that reach. The average error over each calibration reach was within the \pm 0.15 $\mathrm{ft}$ limit; however, one measured water-surface elevation near RM 154.3 in the braided reach was not used, as no reasonable change in the roughness could make the simulated watersurface elevation match the measured water-surface elevation.

Roughness values were adjusted equally for every cross section within a given calibration reach. Table 4 shows the final calibrated Manning's $n$ values of the streambed for each reach. Bank $n$ values were not adjusted from the value of 0.060 used in the previous model (Berenbrock, 2005).

Previous calibration (Berenbrock, 2005) resulted in channel Manning's $n$ values ranging from 0.020 to 0.050 over four separate reaches. Calibrated Manning's $n$ values for this updated model range from 0.023 to 0.045 . These roughness values are in the typical range for stream channels. Roughness values are generally highest in the canyon reach and lower in the braided, straight, and meander reaches. In general, the roughness values decrease as discharge increases. This trend, however, is complicated as side channels and bars are inundated under higher streamflow conditions.

\section{Model Verification}

Model verification consisted of simulating 10 additional events in the fully calibrated model and comparing simulated water-surface elevations to measured values at the gaging stations. Verification events were chosen to meet the same criteria as calibration events, except they represent a greater variation in backwater conditions at the downstream end of the model (table 5; fig. 5). Verification events span discharges from about 4,900 to 52,000 ft $3 / \mathrm{s}$ (table 5; fig. 5). No modifications were made to the calibrated model prior to simulating verification events; only the boundary conditions of discharge and downstream water-surface elevation were changed.

Measured and simulated water-surface elevations were compared at gaging station locations for the verification events (table 6). Model verification events represent a greater range in backwater conditions in the study reach than the calibration events (fig. 5) and represent the potential error in using the given calibration for all possible backwater conditions. Differences between measured and simulated water-surface elevations ranged from $-1.17 \mathrm{ft}$ to $0.94 \mathrm{ft}$ and were generally greatest in the braided reach. The average difference between measured and simulated water-surface elevations was $0.05 \mathrm{ft}$ over the range of events and gaging stations. 


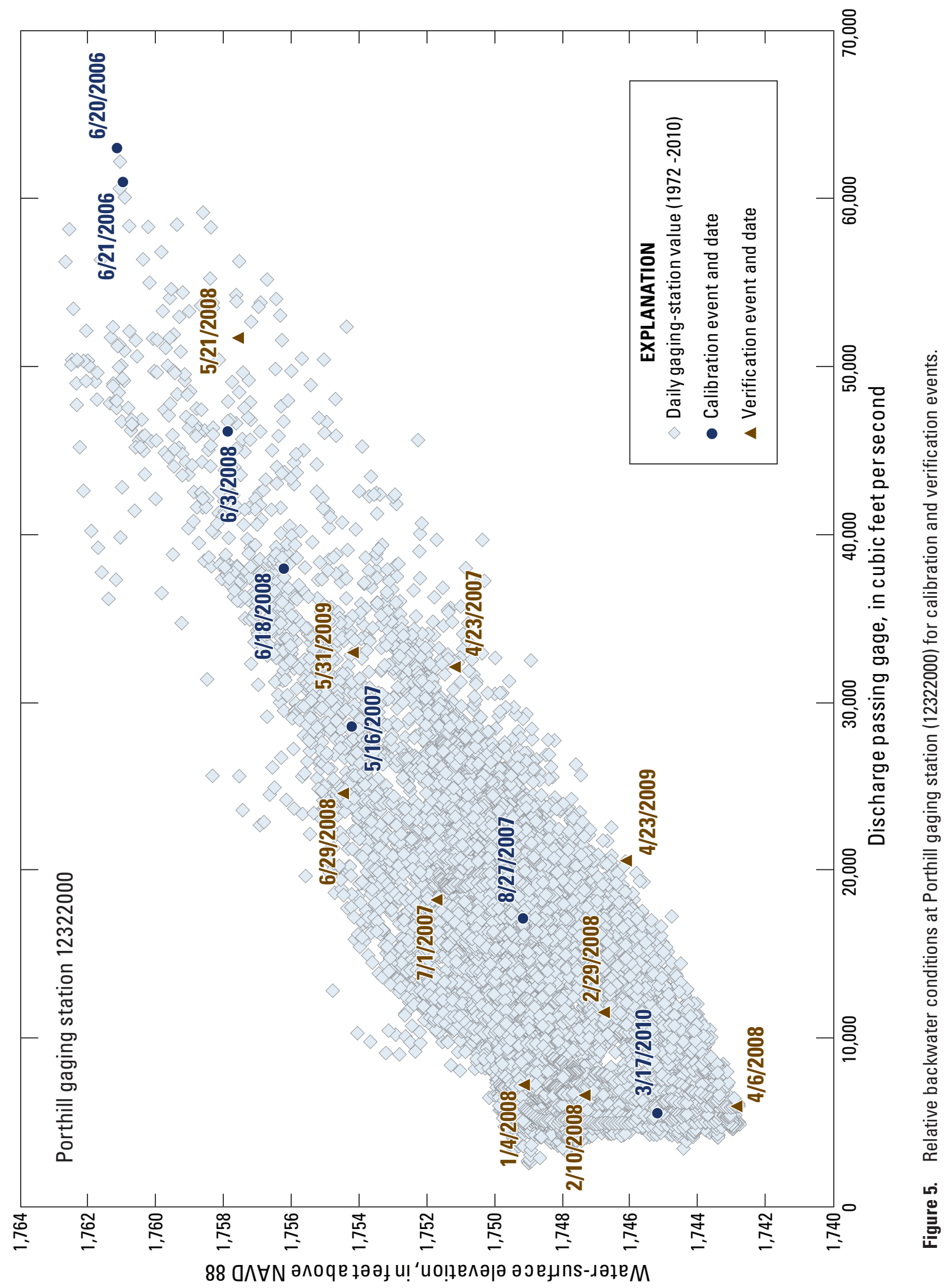




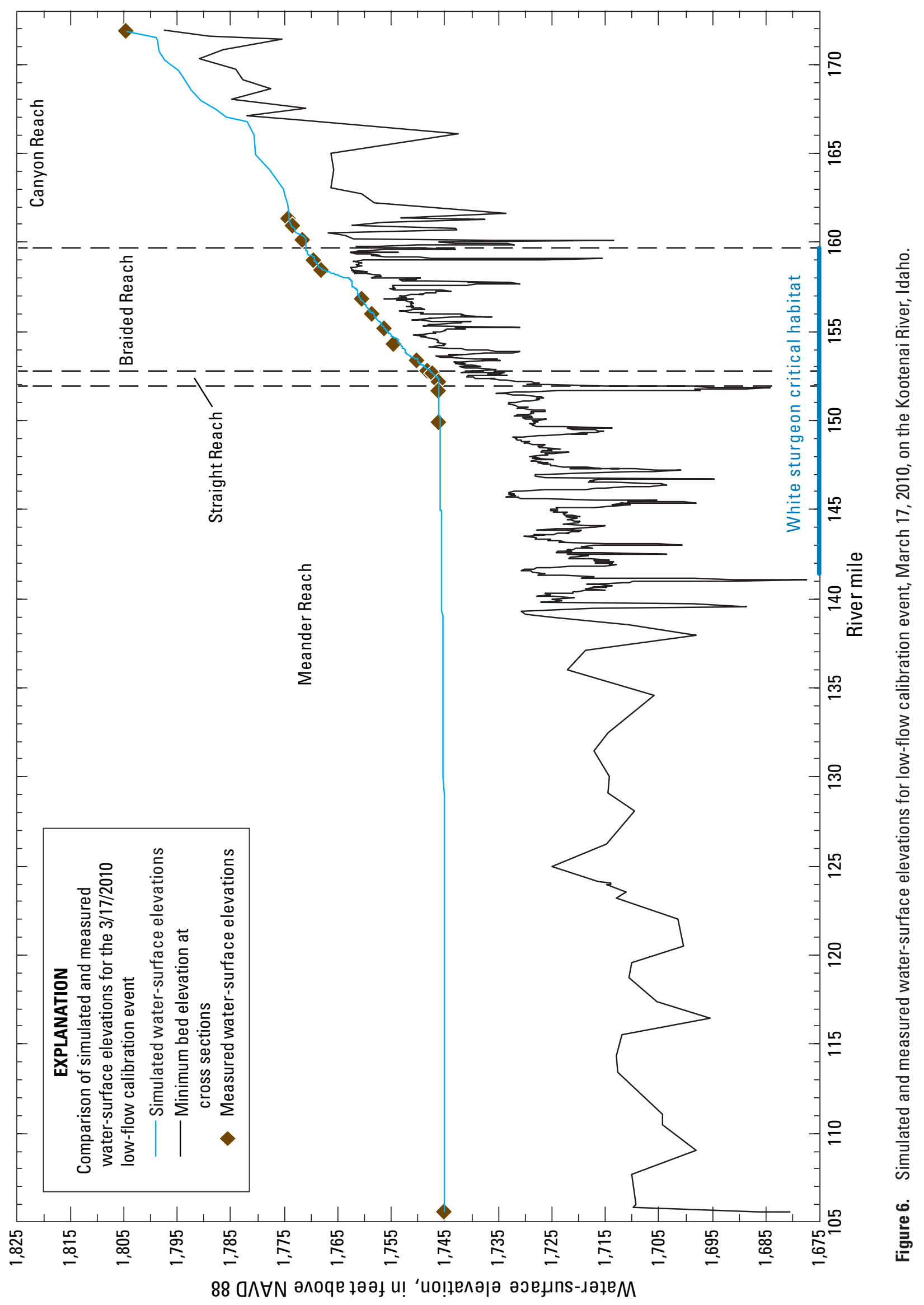


Table 4. Calibrated channel Manning's $n$ roughness values, Kootenai River, Idaho.

[Locations of reaches are shown in figures 2 and $\underline{4}$. Gaging station descriptions are shown in table 1 . Model boundary conditions for calibration events are shown in table 2. Abbreviations $\mathrm{ft}^{3} / \mathrm{s}$, cubic foot per second]

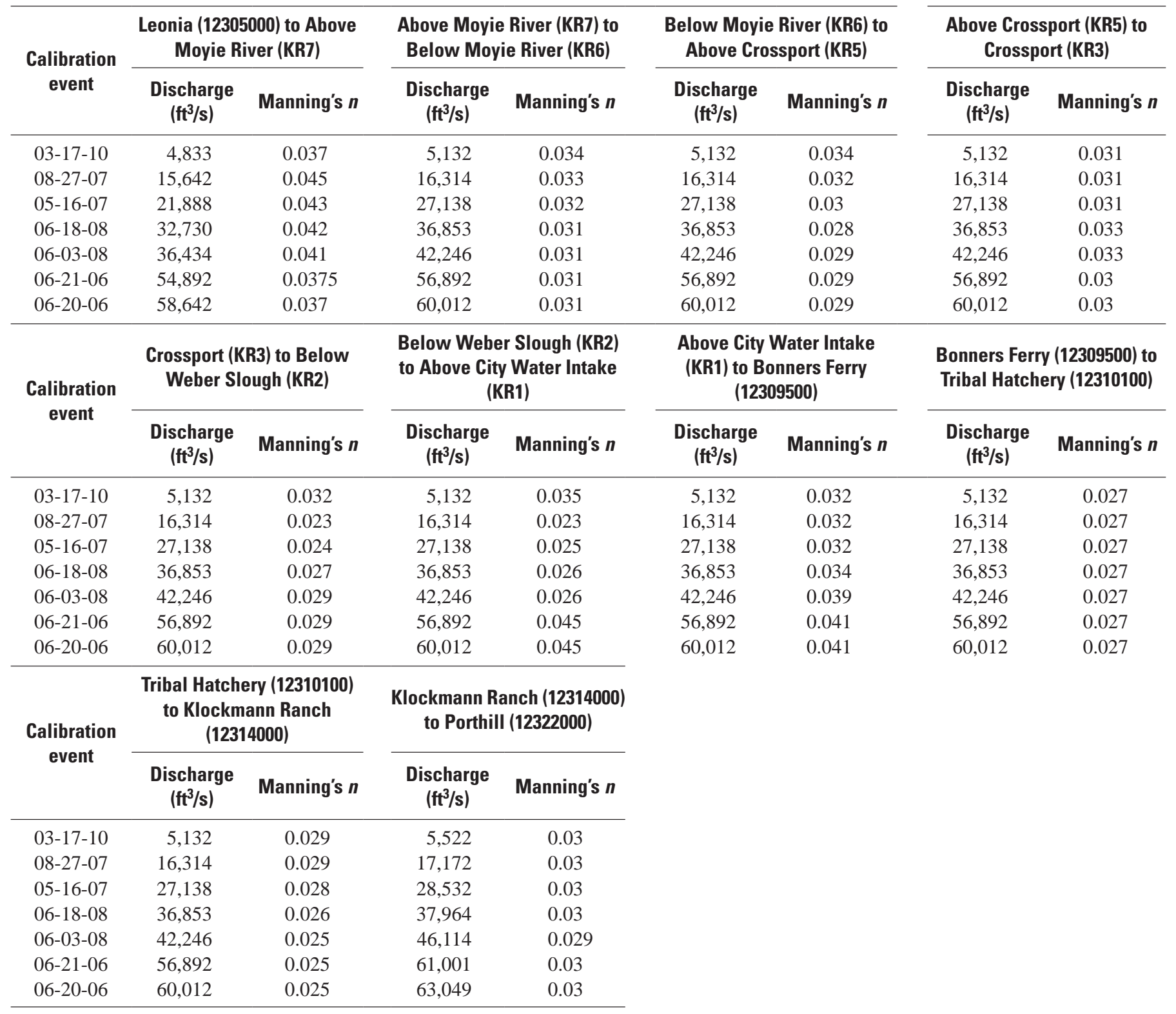


Table 5. Model boundary conditions for verification events, Kootenai River, Idaho.

[Gaging station locations are shown in figures 2 and 4 . Gaging station descriptions are shown in table 1 . Abbreviations $\mathrm{ft}^{3} / \mathrm{s}$, cubic foot per second]

\begin{tabular}{|c|c|c|c|c|}
\hline \multirow[b]{2}{*}{$\begin{array}{c}\text { Verification } \\
\text { event }\end{array}$} & \multicolumn{3}{|c|}{ Discharge in reach $\left(\mathrm{ft}^{3} / \mathrm{s}\right)$} & \multirow{2}{*}{$\begin{array}{c}\text { Downstream } \\
\text { water-surface } \\
\text { elevation (feet) at } \\
\text { Porthill (12322000) }\end{array}$} \\
\hline & $\begin{array}{c}\text { Leonia (12305000) to } \\
\text { Above } \\
\text { Moyie River (KR7) }\end{array}$ & $\begin{array}{c}\text { Above Moyie River (KR7) } \\
\text { to Klockmann Ranch } \\
\text { (12314000) }\end{array}$ & $\begin{array}{l}\text { Klockmann Ranch } \\
(12314000) \text { to } \\
\text { Porthill (12322000) }\end{array}$ & \\
\hline 02-10-08 & 4,874 & 5,039 & 6,614 & $1,747.36$ \\
\hline 04-06-08 & 5,365 & 5,864 & 5,957 & $1,742.88$ \\
\hline 01-04-08 & 5,460 & 5,634 & 7,235 & $1,749.15$ \\
\hline 02-29-08 & 10,566 & 11,144 & 11,553 & $1,746.79$ \\
\hline 07-01-07 & 16,323 & 17,327 & 18,251 & $1,751.73$ \\
\hline 04-23-09 & 16,454 & 20,044 & 20,584 & $1,746.14$ \\
\hline 06-29-08 & 21,729 & 24,148 & 24,588 & $1,754.49$ \\
\hline 05-31-09 & 24,769 & 30,774 & 32,983 & $1,754.20$ \\
\hline $04-23-07$ & 28,814 & 30,846 & 32,125 & $1,751.19$ \\
\hline 05-21-08 & 34,847 & 47,039 & 51,721 & $1,757.59$ \\
\hline
\end{tabular}

Additional model verification consisted of comparing measured and simulated velocities at four sites in the study reach (figs. 7-10). Measured velocities averaged for each of the four cross sections were obtained from discharge measurements during moderate to high streamflow using an acoustic Doppler current profiler to aid in estimating suspended-sediment transport (Fosness and Williams, 2009). Velocity measurements used in this analysis were made between December 2007 and August 2009 at the Kootenai River above Shorty Island (4845421162319, CS 143.585), Kootenai River below Fry Creek (12309490; CS 153.372), Kootenai River at Crossport (4842061161430; CS 156.829), and at Kootenai River below Moyie River (4842231161104; CS 159.783). The measured discharges at all four sites range from about 7,400 to $46,620 \mathrm{ft}^{3} / \mathrm{s}$ and measured average velocities ranged from $1.0 \mathrm{ft} / \mathrm{s}$ to $6.2 \mathrm{ft} / \mathrm{s}$.

A three-parameter relation between discharge, downstream water-surface elevation at Porthill (12322000), and velocity at a given cross section can be expressed in a two-dimensional chart expressing the third parameter (velocity) with lines of equal value. The calibrated model was run for a range of boundary conditions by varying both the discharge and the downstream water-surface elevation at the Porthill gaging station (12322000) to develop the contour lines of equal simulated velocities for each of the four sites. The measured discharge and measured average velocities were also plotted for comparison to simulated velocities, using the daily mean water-surface elevation at Kootenai River at Porthill gaging station (12322000) on the day of each velocity measurement. It is important to note that the velocity measurements were not necessarily made during periods of steady or gradually varied flow, and as such the discharge measured at each site may differ from the discharge at the Porthill gaging station (12322000).

Measured velocities at each site compare relatively closely to the lines of equal simulated velocities. The biggest differences, however, are at cross section 153.372, where simulated velocities are generally lower than measured velocities under given boundary conditions (fig. 8). Cross section 153.372 is located at the downstream end of the braided reach where field observations indicate that the streamflow is concentrated along both the left and right banks and is converging towards the center, and there is a center bar that occasionally shifts and changes geomorphically (fig. 11). This cross section is also located within the typical transition between backwater and free-flowing water, which can create complicated streamflow conditions. For cross sections farther upstream, the lines of equal velocity become more vertical, indicating that the downstream stage at Porthill has less of a backwater effect. It is important to note that several of the measurements were taken on the rising and falling limbs of a storm hydrograph, which can cause incorrect comparisons when the discharge at the sample site is significantly different than at Porthill (12322000). In addition, the backwater condition at the time of velocity measurements were often at the high or low extent of historical conditions, so the average backwater conditions used to calibrate roughness may add to the error. 
Table 6. Measured and simulated water-surface elevations for verification events, Kootenai River, Idaho.

[Gaging station and cross section locations are shown in figure 2. Gaging station descriptions are shown in table 1. Model boundary conditions for verification events are shown in table 5. Difference is Simulated minus Measured. Abbreviations CS, cross section; -, no data]

\begin{tabular}{|c|c|c|c|c|c|c|c|c|c|}
\hline \multirow{3}{*}{$\begin{array}{l}\text { Verification } \\
\quad \text { event }\end{array}$} & \multicolumn{9}{|c|}{ Water-surface elevation (in feet) } \\
\hline & \multicolumn{3}{|c|}{ Leonia (12305000) (CS 171.875) } & \multicolumn{3}{|c|}{ Above Moyie River (KR7) (CS 161.344) } & \multicolumn{3}{|c|}{ Below Moyie River (KR6) (CS 160.07) } \\
\hline & Measured & Simulated & Difference & Measured & Simulated & Difference & Measured & Simulated & Difference \\
\hline $02-10-08$ & $1,804.76$ & $1,804.76$ & 0.00 & - & $1,774.20$ & - & - & $1,771.04$ & - \\
\hline 04-06-08 & $1,805.04$ & $1,804.98$ & -0.06 & - & $1,774.79$ & - & - & $1,771.61$ & - \\
\hline 01-04-08 & $1,805.09$ & $1,805.02$ & -0.07 & - & $1,774.64$ & - & - & $1,771.47$ & - \\
\hline 04-23-09 & $1,809.80$ & $1,809.52$ & -0.28 & - & $1,779.76$ & - & $1,775.82$ & $1,775.73$ & -0.09 \\
\hline 06-29-08 & $1,811.20$ & $1,811.23$ & 0.03 & $1,780.31$ & $1,780.70$ & 0.39 & $1,775.94$ & $1,776.52$ & 0.58 \\
\hline 05-31-09 & $1,812.38$ & $1,812.30$ & -0.08 & - & $1,782.05$ & - & $1,777.92$ & $1,777.65$ & -0.27 \\
\hline 04-23-07 & $1,813.38$ & $1,813.57$ & 0.19 & - & $1,782.06$ & - & $1,778.07$ & $1,777.66$ & -0.41 \\
\hline 05-21-08 & $1,815.09$ & $1,815.10$ & 0.01 & $1,784.54$ & $1,785.07$ & 0.53 & $1,779.99$ & $1,780.33$ & 0.34 \\
\hline $\begin{array}{l}\text { Verification } \\
\text { event }\end{array}$ & \multicolumn{3}{|c|}{ Above Crossport (KR5) (CS 158.123) } & \multicolumn{3}{|c|}{ Crossport (KR3) (CS 156.829) } & \multicolumn{3}{|c|}{ Below Weber Slough (KR2) (CS 155.382) } \\
\hline 04-06-08 & - & $1,764.94$ & - & $1,761.36$ & $1,761.26$ & -0.10 & $1,756.96$ & $1,757.25$ & 0.29 \\
\hline 01-04-08 & - & $1,764.85$ & - & $1,761.34$ & $1,761.15$ & -0.19 & $1,756.94$ & $1,757.17$ & 0.23 \\
\hline $02-29-08$ & - & $1,766.81$ & - & $1,762.94$ & $1,763.08$ & 0.14 & 1,758.33 & $1,758.54$ & 0.21 \\
\hline 07-01-07 & $1,768.52$ & $1,768.53$ & 0.01 & $1,764.36$ & $1,764.30$ & -0.06 & 1,759.34 & $1,759.43$ & 0.09 \\
\hline 04-23-09 & - & 1,769.21 & - & $1,765.10$ & $1,764.90$ & -0.20 & $1,759.75$ & 1,759.87 & 0.12 \\
\hline 06-29-08 & $1,770.18$ & $1,770.16$ & -0.02 & $1,765.91$ & $1,765.75$ & -0.16 & $1,760.72$ & 1,761.12 & 0.40 \\
\hline 05-31-09 & - & $1,771.74$ & - & $1,767.25$ & $1,767.13$ & -0.12 & $1,762.50$ & $1,762.59$ & 0.09 \\
\hline 04-23-07 & $1,771.48$ & $1,771.74$ & 0.26 & $1,766.78$ & $1,767.09$ & 0.31 & $1,761.26$ & 1,762.08 & 0.82 \\
\hline 05-21-08 & $1,774.74$ & $1,774.97$ & 0.23 & $1,770.10$ & $1,770.58$ & 0.48 & $1,766.69$ & 1,767.63 & 0.94 \\
\hline $\begin{array}{l}\text { Verification } \\
\text { event }\end{array}$ & \multicolumn{3}{|c|}{$\begin{array}{l}\text { Above City Water Intake (KR1) } \\
\text { (CS 154.059) }\end{array}$} & \multicolumn{3}{|c|}{$\begin{array}{c}\text { Bonners Ferry (12309500) } \\
\text { (CS 152.79) }\end{array}$} & \multicolumn{3}{|c|}{$\begin{array}{c}\text { Tribal Hatchery (12310100) } \\
\text { (Average of CS } 149.947 \text { and 149.91) }\end{array}$} \\
\hline 06-29-08 & $1,759.46$ & $1,759.73$ & 0.27 & $1,758.79$ & $1,758.83$ & 0.04 & $1,758.23$ & 1,758.29 & 0.06 \\
\hline 05-31-09 & - & $1,761.57$ & - & $1,760.61$ & $1,760.66$ & 0.05 & 1,759.99 & $1,760.00$ & 0.01 \\
\hline 04-23-07 & - & $1,760.57$ & - & 1,758.92 & $1,759.31$ & 0.39 & $1,758.01$ & 1,758.48 & 0.46 \\
\hline 05-21-08 & 1,766.39 & $1,767.07$ & 0.68 & $1,765.63$ & $1,766.17$ & 0.54 & $1,764.88$ & $1,765.41$ & 0.53 \\
\hline \multirow[t]{2}{*}{$\begin{array}{l}\text { Verification } \\
\text { event }\end{array}$} & \multicolumn{3}{|c|}{$\begin{array}{l}\text { Klockmann Ranch (12314000) } \\
\text { (CS 139.562) }\end{array}$} & $\begin{array}{c}\text { Porthill } \\
\text { (12322000) } \\
\text { (CS 105.603) }\end{array}$ & & & & & \\
\hline & Measured & Simulated & Difference & Measured & & & & & \\
\hline 02-10-08 & $1,747.73$ & $1,747.89$ & 0.16 & $1,747.36$ & & & & & \\
\hline 04-06-08 & $1,743.85$ & $1,743.76$ & -0.09 & $1,742.88$ & & & & & \\
\hline 01-04-08 & $1,749.54$ & $1,749.64$ & 0.10 & $1,749.15$ & & & & & \\
\hline 02-29-08 & $1,748.43$ & $1,748.39$ & -0.04 & $1,746.79$ & & & & & \\
\hline 07-01-07 & 1,753.68 & $1,753.68$ & 0.00 & $1,751.73$ & & & & & \\
\hline 04-23-09 & $1,750.45$ & $1,750.56$ & 0.11 & $1,746.14$ & & & & & \\
\hline 06-29-08 & $1,757.06$ & $1,756.95$ & -0.11 & $1,754.49$ & & & & & \\
\hline 05-31-09 & $1,758.41$ & $1,758.33$ & -0.08 & $1,754.20$ & & & & & \\
\hline 04-23-07 & $1,756.08$ & $1,756.38$ & 0.30 & 1,751.19 & & & & & \\
\hline 05-21-08 & 1,763.19 & $1,763.57$ & 0.38 & $1,757.59$ & & & & & \\
\hline
\end{tabular}




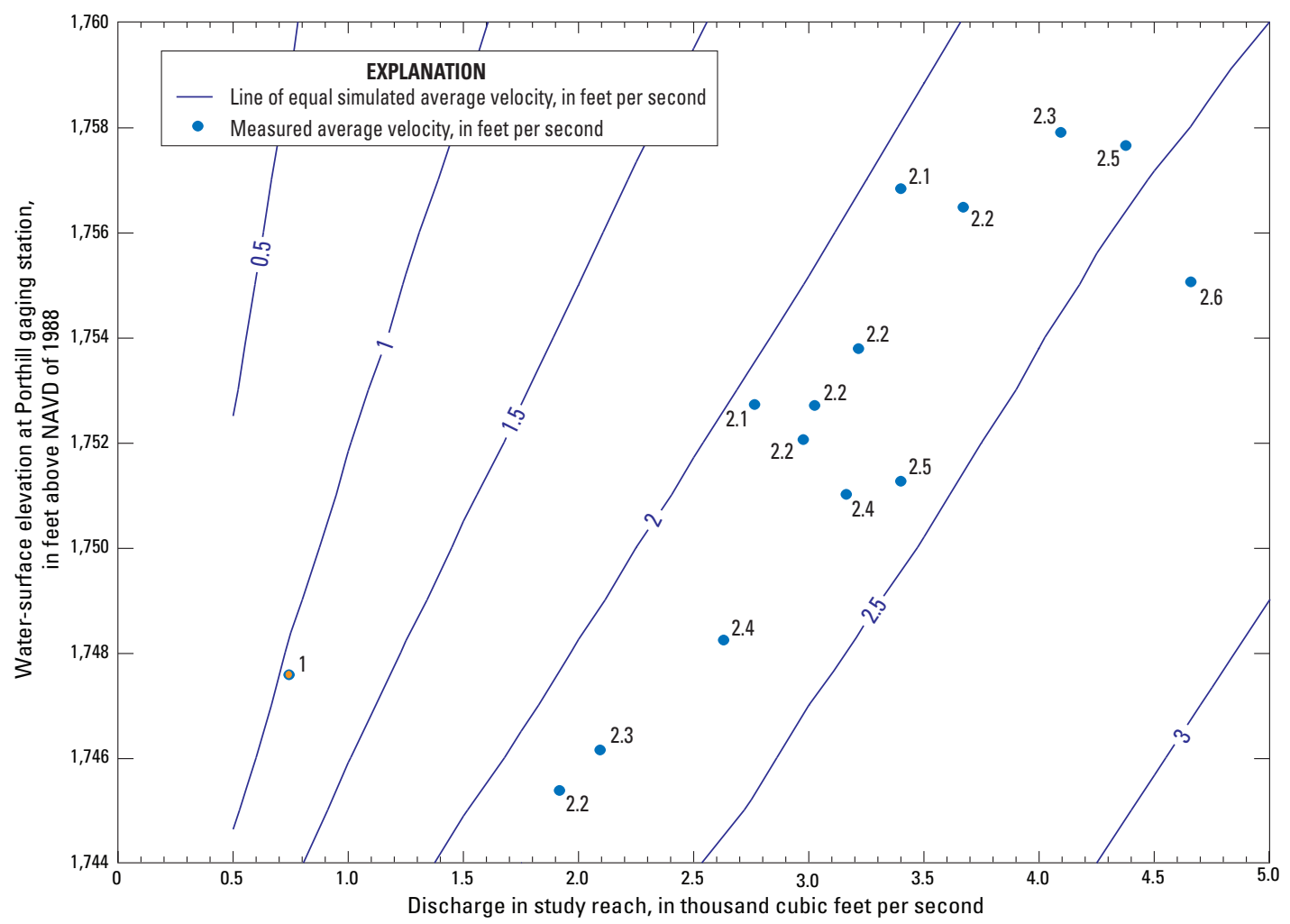

Figure 7. Simulated and measured average velocities at cross section 143.585 relative to discharge in the study reach and water-surface elevations at Porthill gaging station (12322000).

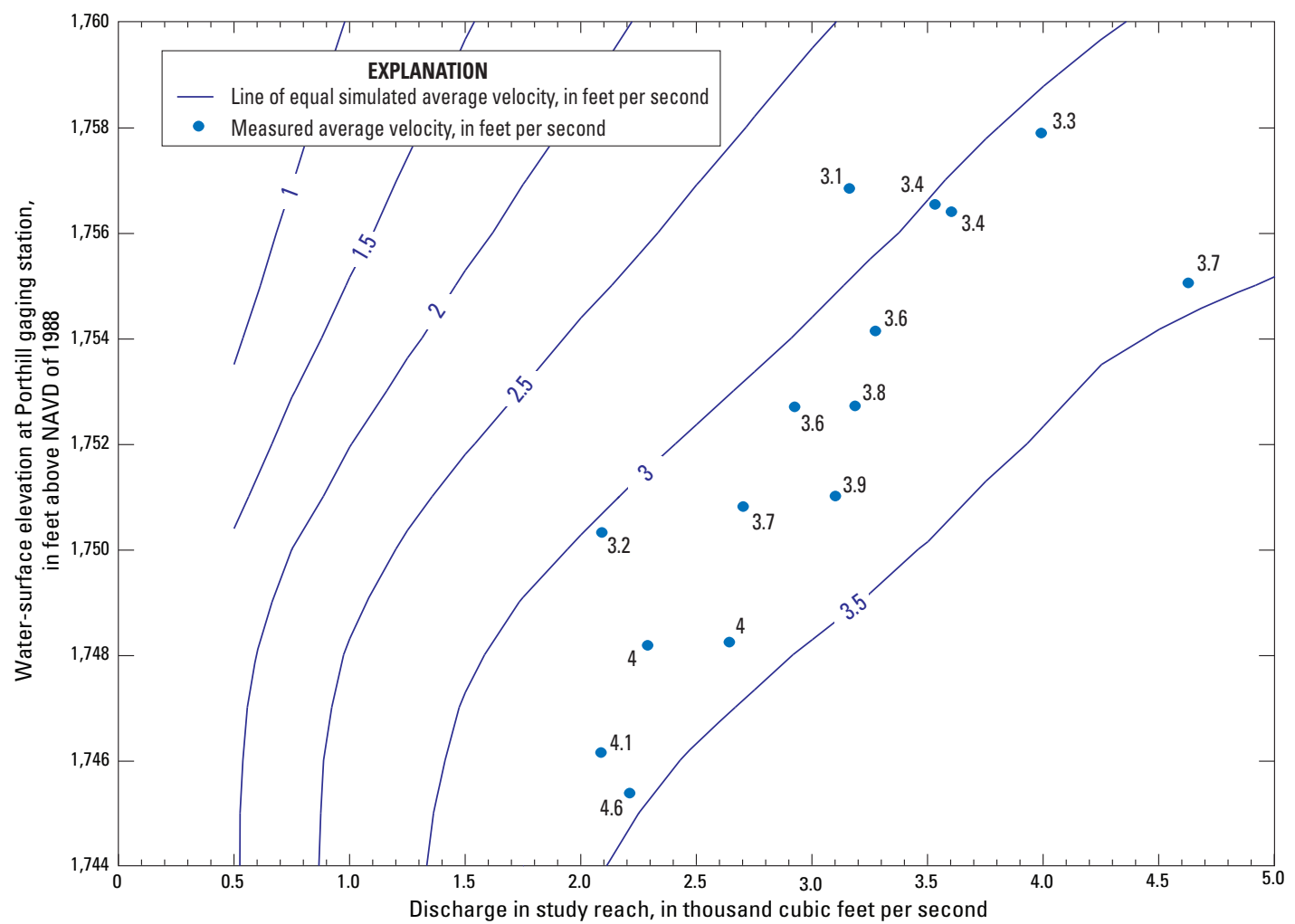

Figure 8. Simulated and measured average velocities at cross section 153.372 relative to discharge in the study reach and water-surface elevations at Porthill gaging station (12322000). 


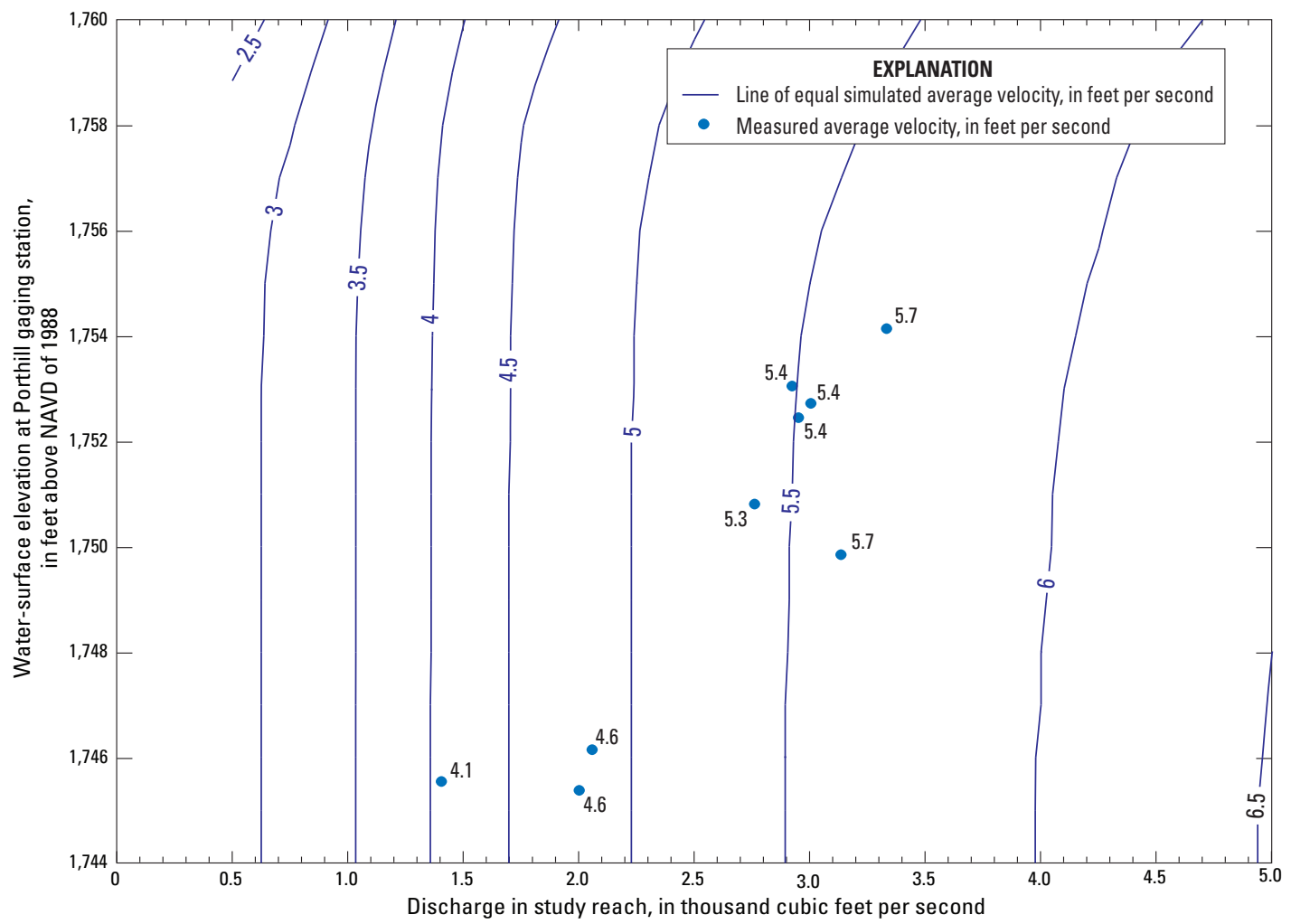

Figure 9. Simulated and measured average velocities at cross section 156.829 relative to discharge in the study reach and water-surface elevations at Porthill gaging station (12322000).

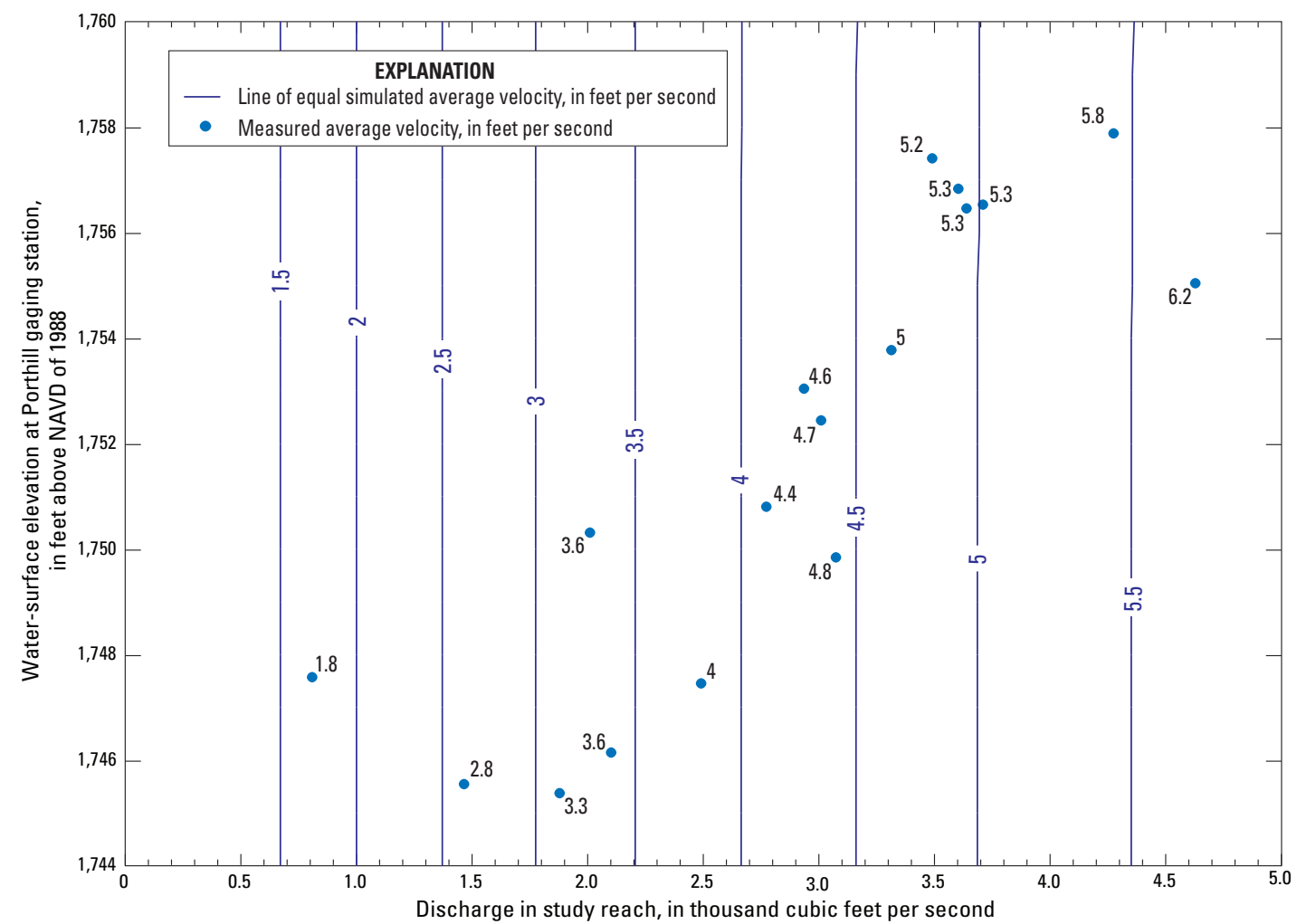

Figure 10. Simulated and measured average velocities at cross section 159.783 relative to discharge in the study reach and water-surface elevations at Porthill gaging station (12322000). 


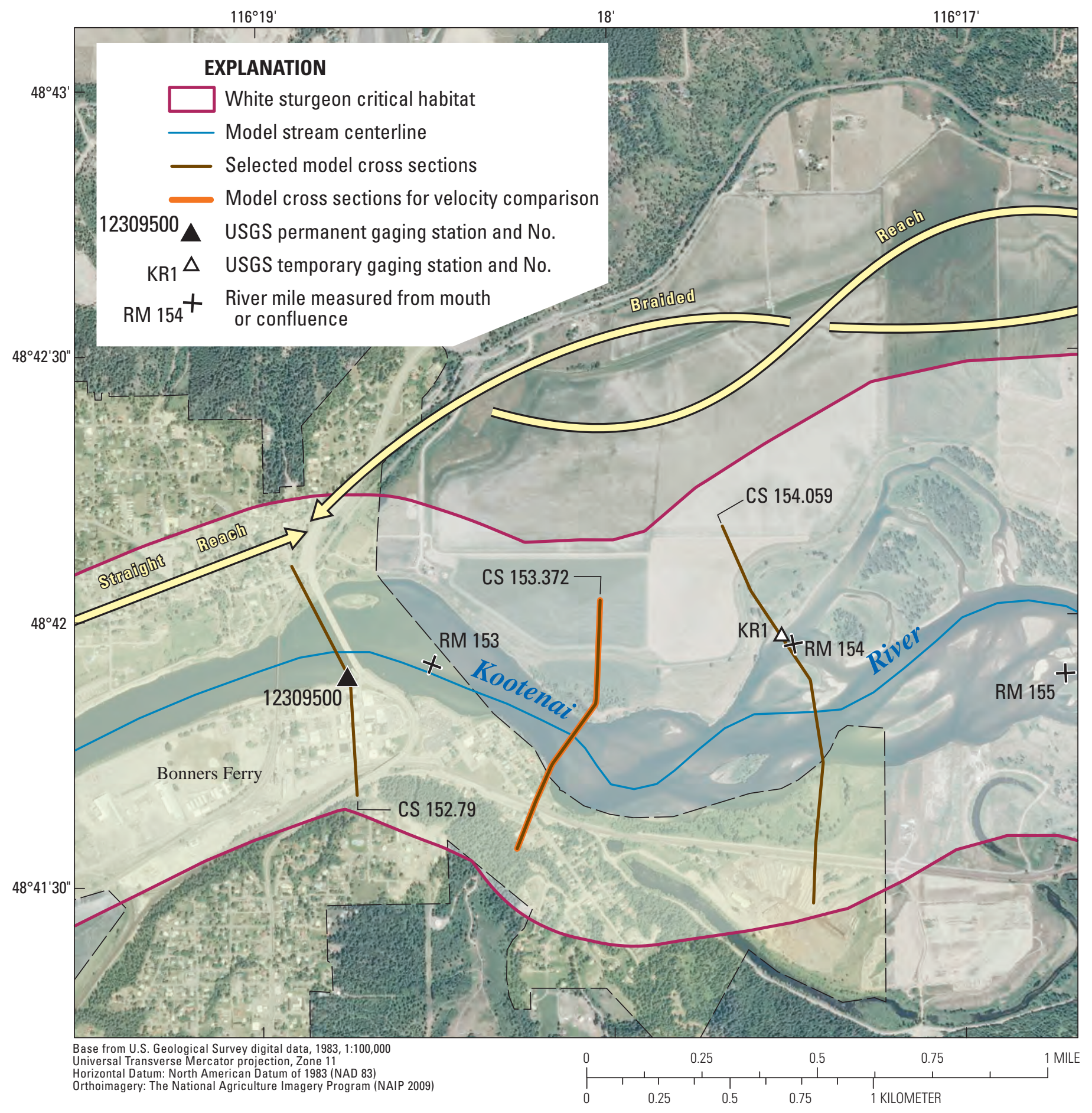

Figure 11. The Kootenai River showing gravel bars near Bonners Ferry, Idaho. 


\section{Sensitivity Analysis}

The sensitivity of the model to variations in channel and bank roughness coefficients was determined by comparing simulated water-surface elevations for changes in the Manning's $n$ value. The relative changes in water-surface elevations can provide insight into how the roughness parameter affects the model output. The calibrated crosssection geometry and boundary conditions (discharge and water-surface elevation from table 2) were not changed for any of the sensitivity model runs.

\section{Channel Roughness}

The sensitivity of the model results (table 7) to a 10-percent perturbation in the channel roughness was determined for the calibration event occurring on May 16, 2007 (see table 2 for model boundary conditions). This corresponds to a mid-range calibration event that nearly approximates bankfull discharge for the majority of the study reach. The calibrated Manning's $n$ values of the channel were varied by \pm 10 percent for each calibration reach. The boundary conditions at the upstream and downstream cross sections were not altered for the sensitivity analysis.

Results of the sensitivity analysis for the channel $n$ values for this mid-range calibration event (table 7) indicate that the simulated water-surface elevations are sensitive to changes in Manning's $n$ in the channel. Average differences in water-surface elevation for each calibration reach range from about $\pm 0.7 \mathrm{ft}$ for a \pm 10 percent change in streambed $n$ values. Average differences are greater than the calibration threshold ( $\pm 0.15 \mathrm{ft}$ ), indicating that the model is sensitive to changes in the channel roughness.

\section{Bank Roughness}

Sensitivity of the model results to a range of perturbations in the bank roughness (table 8) was determined for the highest calibration event occurring on June 20, 2006, which would cause the most inundation of all calibration events. Model boundary conditions were not altered from the calibrated model for the sensitivity analysis simulations (table 2). Channel roughnesses were set to calibrated values (table 4). The calibrated bank $n$ values were first varied by \pm 10 percent for each reach. Results of the sensitivity analysis to changes in the bank roughness by \pm 10 percent (table 8 ) were well within the $\pm 0.15 \mathrm{ft}$ calibration limit. The calibrated bank $n$ were then decreased by -66 percent ( 0.33 times) and increased by +300 percent (3.0 times).

Results of the sensitivity analysis for the bank Manning's $n$ show that the model results are not significantly sensitive to changes in the bank roughness (table 8). Average differences in water-surface elevations were well within the $\pm 0.15 \mathrm{ft}$ calibration limit when the bank roughnesses were varied by \pm 10 percent. For the -66 percent and +300 percent runs, the average differences in the straight and meander reaches were also within the $\pm 0.15 \mathrm{ft}$ calibration limit. In the braided and canyon reach, differences ranged from -0.25 to $0.11 \mathrm{ft}$. Watersurface elevation differences were lower for changes in the bank roughness than channel roughness; therefore the model is much less sensitive to changes in Manning's $n$ values for bank roughness than for channel roughness.

Table 7. Sensitivity of simulated water-surface elevations to changes in channel roughness coefficients for the May 16, 2007, calibration event, Kootenai River, Idaho.

[Positive value indicates an increase in simulated water-surface elevation as compared with the calibrated model; negative value indicates a decrease in simulated water-surface elevation as compared with the calibrated model. Abbreviations -, minus; +, plus]

\begin{tabular}{|c|c|c|c|}
\hline \multirow[t]{2}{*}{ Reach } & \multirow[t]{2}{*}{$\begin{array}{l}\text { Number of cross } \\
\text { sections in reach }\end{array}$} & \multicolumn{2}{|c|}{$\begin{array}{l}\text { elevation, in feet, when channel } \\
\text { Manning's } n \text { is changed by: }\end{array}$} \\
\hline & & -10 percent & +10 percent \\
\hline Leonia (12305000) to Above Moyie River (KR7) & 19 & -0.74 & 0.71 \\
\hline Above Moyie River (KR7) to Below Moyie River (KR6) & 11 & -0.48 & 0.47 \\
\hline Below Moyie River (KR6) to Above Crossport (KR5) & 64 & -0.41 & 0.41 \\
\hline Above Crossport (KR5) to Crossport (KR3) & 43 & -0.51 & 0.48 \\
\hline Crossport (KR3) to Below Weber Slough (KR2) & 51 & -0.46 & 0.45 \\
\hline Below Weber Slough (KR2) to Above City Water Intake (KR1) & 33 & -0.61 & 0.62 \\
\hline Above City Water Intake (KR1) to Bonners Ferry (12309500) & 40 & -0.69 & 0.7 \\
\hline Bonners Ferry (12309500) to Tribal Hatchery (12310100) & 80 & -0.68 & 0.69 \\
\hline Tribal Hatchery (12310100) to Klockmann Ranch ${ }^{1}(12314000)$ & 283 & -0.6 & 0.61 \\
\hline Klockmann Ranch (12314000) to Porthill (12322000) & 40 & -0.26 & 0.27 \\
\hline Entire model ${ }^{1}$ & 664 & -0.56 & 0.57 \\
\hline
\end{tabular}

${ }^{1}$ Excluding the Shorty Island side channel reach. 
Table 8. Sensitivity of simulated water-surface elevations to changes in bank roughness coefficients for the June 20, 2006, high-flow calibration event, Kootenai River, Idaho.

[Positive value indicates an increase in simulated water-surface elevation as compared with the calibrated model; negative value indicates a decrease in simulated water-surface elevation as compared with the calibrated model. Abbreviations -, minus; +, plus]

\begin{tabular}{|c|c|c|c|c|c|}
\hline \multirow{2}{*}{ Reach } & \multirow{2}{*}{$\begin{array}{c}\text { Number } \\
\text { of cross } \\
\text { sections in } \\
\text { reach }\end{array}$} & \multicolumn{4}{|c|}{$\begin{array}{l}\text { Average difference in water-surface elevation, in feet, } \\
\text { when bank Manning's } n \text { is changed by: }\end{array}$} \\
\hline & & -10 percent & +10 percent & -66 percent & +300 percent \\
\hline Leonia (12305000) to Above Moyie River (KR7) & 19 & -0.01 & 0.01 & -0.12 & 0.06 \\
\hline Above Moyie River (KR7) to Below Moyie River (KR6) & 11 & -0.02 & 0.01 & -0.25 & 0.11 \\
\hline Below Moyie River (KR6) to Above Crossport (KR5) & 64 & -0.01 & 0.01 & -0.21 & 0.1 \\
\hline Below Weber Slough (KR2) to Above City Water Intake (KR1) & 33 & -0.01 & 0 & -0.1 & 0.03 \\
\hline Above City Water Intake (KR1) to Bonners Ferry (12309500) & 40 & 0 & 0 & -0.05 & 0.02 \\
\hline Bonners Ferry (12309500) to Tribal Hatchery (12310100) & 80 & 0 & 0 & -0.03 & 0.01 \\
\hline Tribal Hatchery (12310100) to Klockmann Ranch ${ }^{1}$ (12314000) & 283 & 0 & 0 & -0.04 & 0.01 \\
\hline Klockmann Ranch (12314000) to Porthill (12322000) & 40 & 0 & 0 & -0.01 & 0 \\
\hline
\end{tabular}

${ }^{1}$ Excluding the Shorty Island side channel reach.

\section{Simulation of Hydraulic Characteristics of the Kootenai River}

Model results for calibration events are included to show typical hydraulic characteristics for the entire study reach at average backwater conditions. Simulated water-surface elevation and minimum channel elevation, maximum channel depths, and average velocities are presented for all seven calibration events (figs. 12-14).

Water-surface elevations at the downstream and upstream extent of the model range from about 1,745 to $1,820 \mathrm{ft}$ for the calibration events (fig. 12). Simulated water-surface profiles have an increased slope in the braided and canyon reaches compared to those in the straight and meander reaches. Backwater effects extend farther upstream for larger calibration events. The minimum streambed-elevation point for each cross section (thalweg) is also plotted. Although the variations in local bed elevations are considerable, the overall slope of the bed is steeper in slope for the canyon, braided, and straight reaches, transitioning to lower slopes in the meander reach.

Simulated maximum channel depths range from about 4.2 to $90.4 \mathrm{ft}$ over the range of calibration events (fig. 13). The maximum channel depths at model cross sections are generally largest in the meander reach and smallest in the braided reach. However, some of the largest maximum channel depths are within the braided, straight, and upper meander reaches where localized scour holes are represented in model cross sections. In general, the maximum channel depth increases in the downstream direction.

Simulated average cross-section velocities for all calibration events range from about 0.4 to $8.3 \mathrm{ft} / \mathrm{s}$ (fig. 14). In the canyon, straight, and meander reaches, the velocities generally increase as the discharge increases. However, this trend is not apparent in the braided reach. Streamflow is complex through the braided reach; as discharge increases, islands become inundated and side channels become active, which contribute to the average velocity. Average velocities are generally highest in the canyon reach and lowest in the meander reach. The greatest variation in the velocities is in the braided reach.

In addition, the simulated water-surface elevation and the minimum channel elevation, maximum channel depths, and average velocities for all seven calibration events are shown where model resolution is most improved between RMs 140 and 160, which includes the white sturgeon critical habitat (RMs 141.4 to 159.7) (figs. 15-17). 


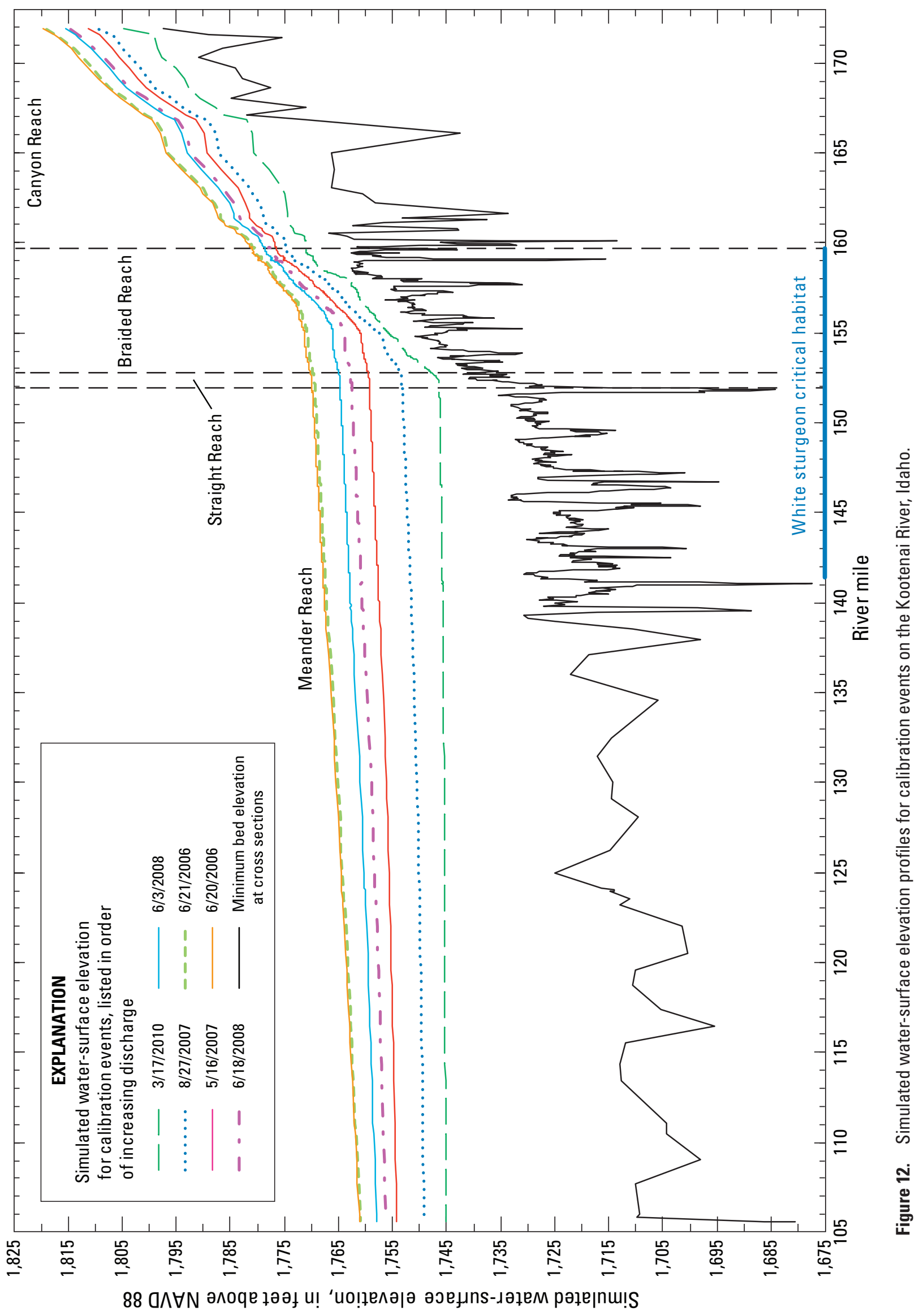




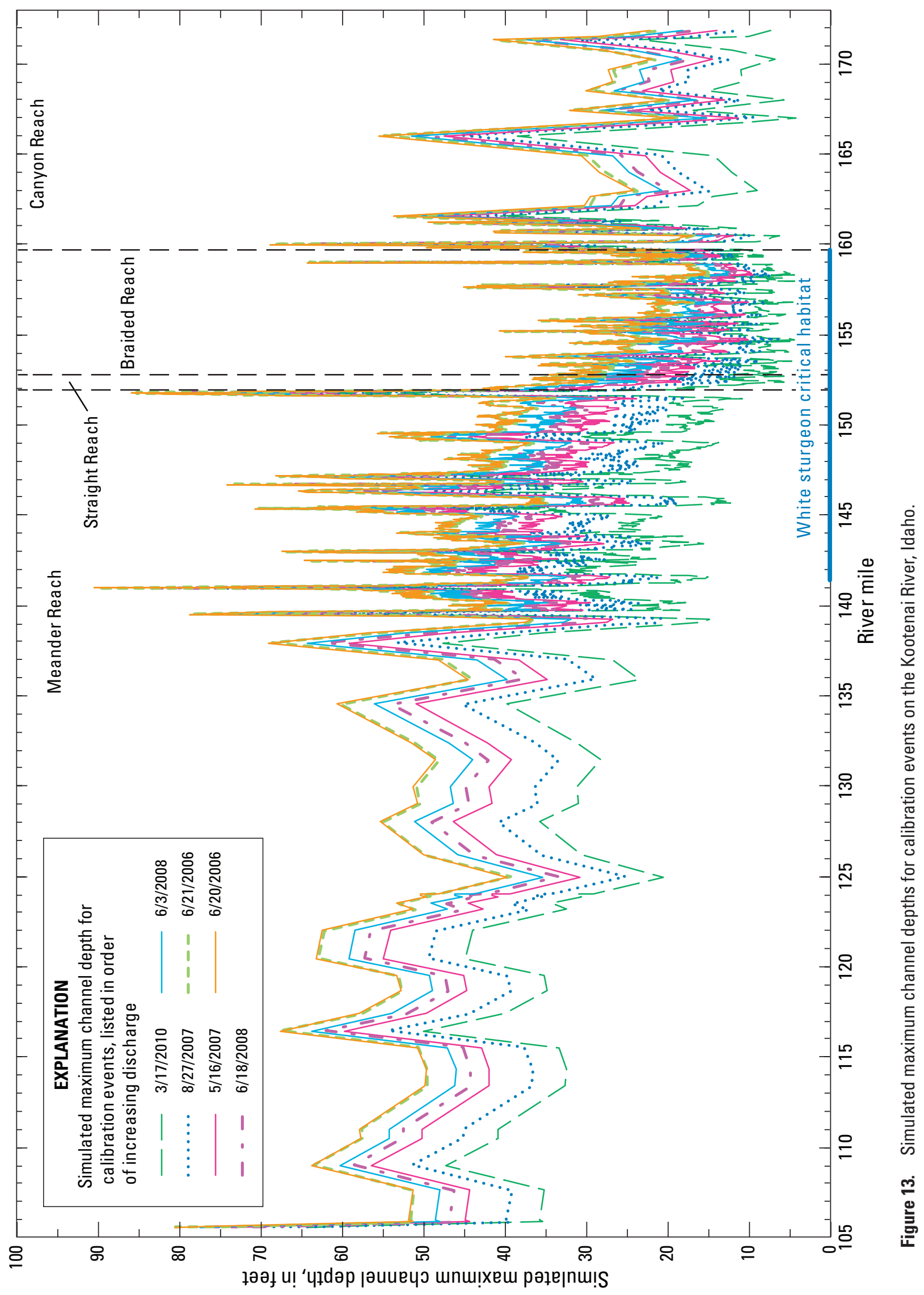




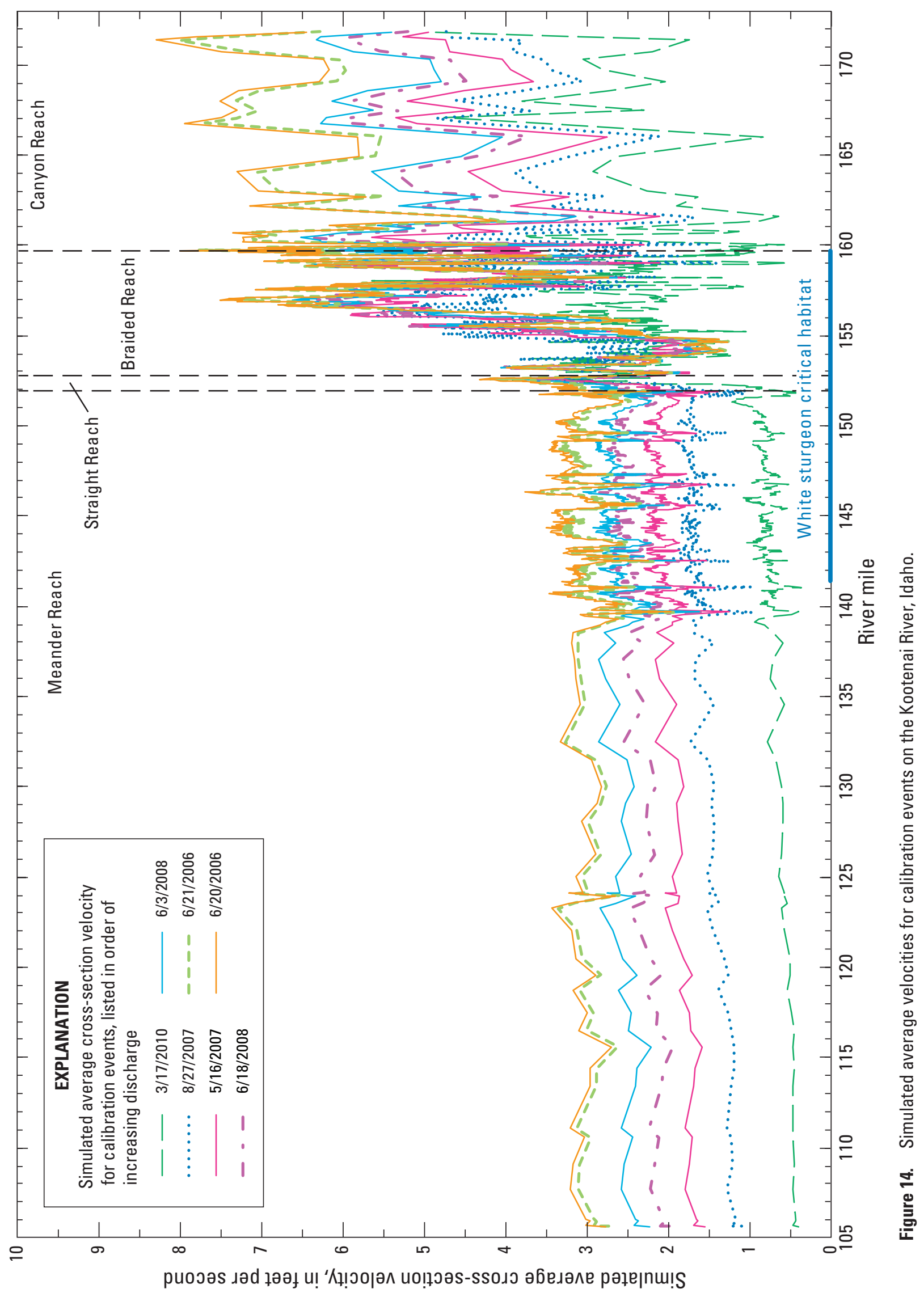




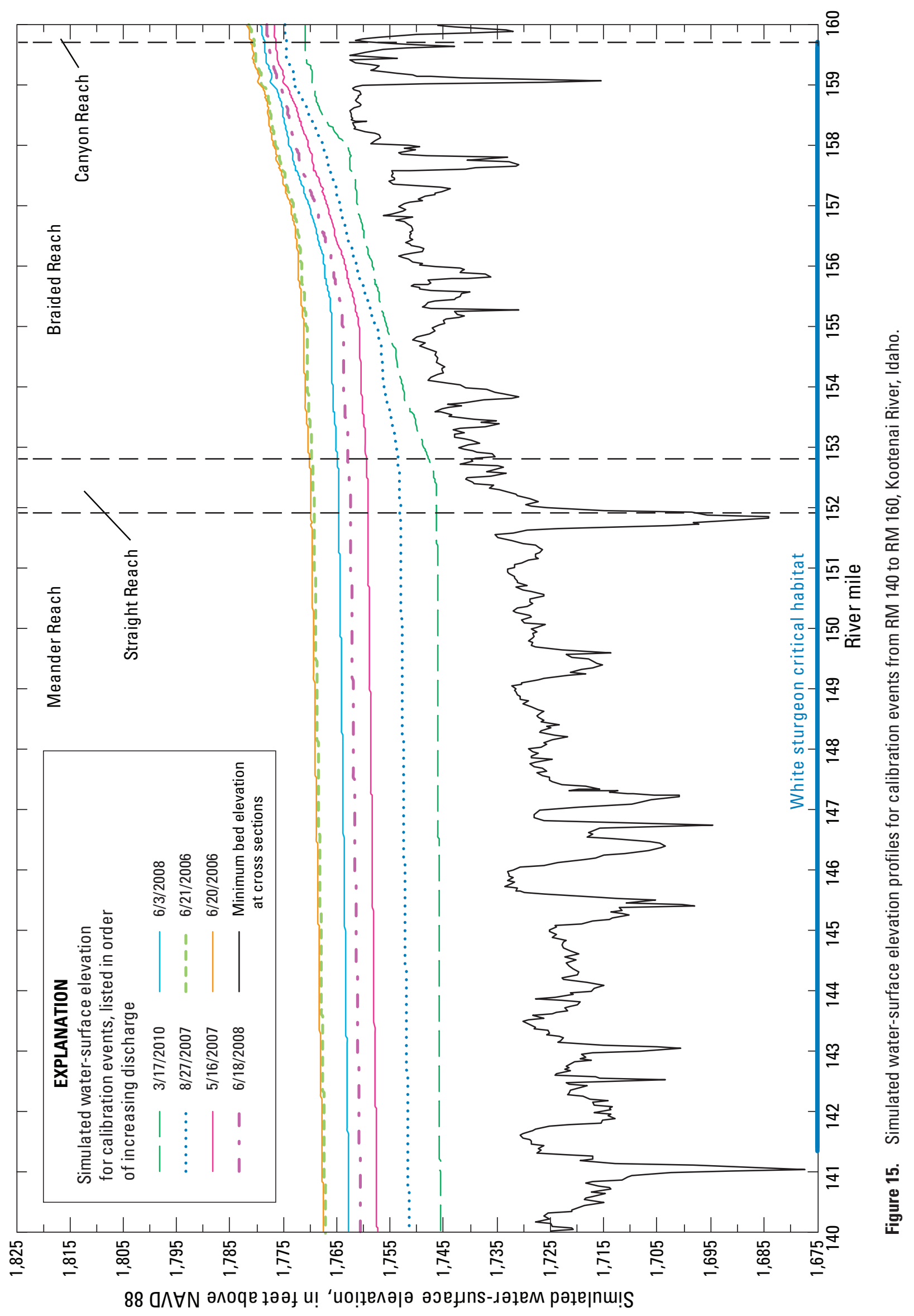




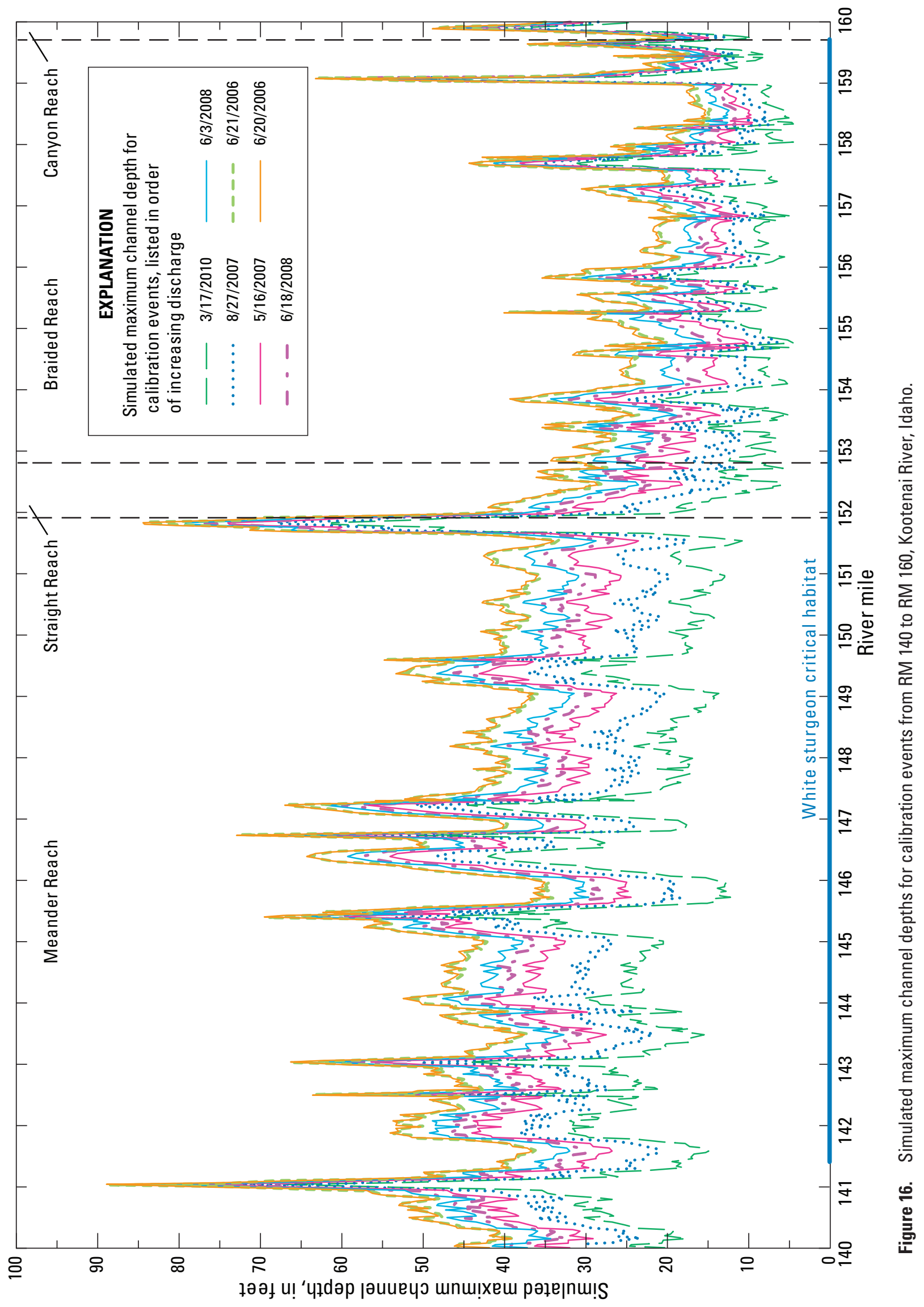




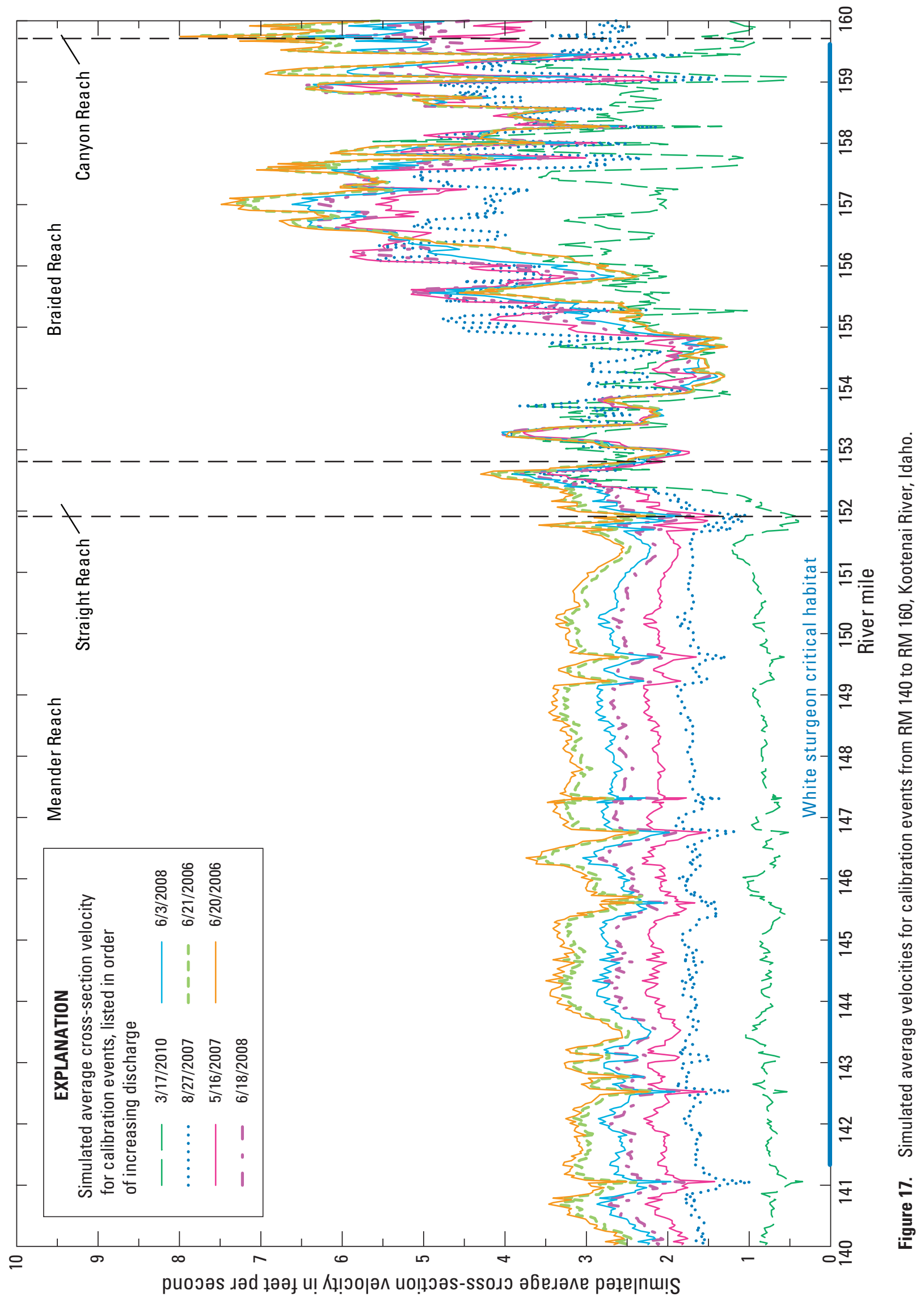




\section{Model Limitations}

It is important to understand the limitations of this model when interpreting the results. Many simplifying assumptions were made about the riverine system in the HEC-RAS computer model. The river was assumed to be under steady, 1-D, and gradually varied streamflow conditions. The only exception was at structures where momentum or other empirical equations were used (Brunner, 2010a; 2010b; Warner and others, 2010).

This model successfully simulates water-surface elevations throughout the Kootenai River between Leonia and Porthill over the range of calibrated discharges from 4,800 to $63,000 \mathrm{ft}^{3} / \mathrm{s}$. However, the 1 -D model is unable to account for variations in velocities or water-surface elevations within a particular cross section, especially throughout the braided reach. The model was run with stable-bed conditions, and sediment-transport processes were not simulated. Calibration events were chosen to represent average backwater conditions at the downstream model boundary. There may be a future opportunity to develop multiple calibration sets representing different seasonal backwater conditions in the study reach. More data will become available for calibration as operation of the gaging stations continues throughout the study reach.

A limitation of the Berenbrock (2005) model was the low number of gaging stations and low resolution bathymetry in the critical habitat. Only five gaging stations were used for nine calibration events, and long reaches were treated as having similar roughness, while in reality the channel characteristics varied along that reach. This updated model more accurately captures the variation in roughness by calibrating to eleven gaging stations throughout the study reach, especially improving the calibration in the braided reach due to the additional USGS temporary gaging stations.

Even with its limitations, this model is a useful tool in understanding and predicting the hydraulic conditions in the Kootenai River between Leonia and Porthill. Model performance was most improved between RMs 140 and 160 , encompassing the white sturgeon critical habitat in the braided, straight, and meander reaches.

\section{Summary}

A one-dimensional hydraulic model was developed for 66 miles of the Kootenai River in Idaho, based on previous modeling work (Berenbrock, 2005), to include more detailed and updated bathymetry and calibration data. The updated model includes 694 cross sections from river miles (RMs) 105.6 to 171.9 of the Kootenai River in Idaho. Bathymetric surveys were conducted from 2002 to 2009 in the study reach between RMs 138 and 161.4. A LIDAR survey was flown in the Kootenai Valley in 2005 between RMs 105.6 and 159.5 to characterize the floodplain topography. Six new temporary gaging stations installed between RMs 154.1 and 161.2 were used along with the five permanent gaging stations in this updated calibration. Eleven gaging stations and one low-flow synoptic survey provided seven calibration events for the model. Measured discharges used for model calibration ranged from about 4,800 to 63,000 cubic feet per second $\left(\mathrm{ft}^{3} / \mathrm{s}\right)$, and measured water-surface elevations ranged from about 1,745 to 1,820 feet (ft) throughout the model from downstream to upstream for the simulated discharges. Calibration was considered adequate when the difference between the simulated and measured water-surface elevations was less than $\pm 0.15 \mathrm{ft}$. Model verification consisted of comparing simulated and measured water-surface elevations at gaging stations for 10 additional events with discharges ranging from about 4,900 to $52,000 \mathrm{ft}^{3} / \mathrm{s}$ covering a range of backwater conditions. Average water-surface-elevation error in the verification simulations was $0.05 \mathrm{ft}$, with the error ranging from -1.17 to $0.94 \mathrm{ft}$ over the range of events and gaging stations. In addition, velocity measurements at four sites over a range of discharges from about 7,400 to $46,600 \mathrm{ft}^{3} / \mathrm{s}$, with measured average velocities ranging from about 1.0 to $6.2 \mathrm{ft} / \mathrm{s}$, were graphically compared to simulated average velocities. The comparison indicated that simulated average velocities closely matched the measured average velocities, with the exception of one site in the braided reach that has complex, three-dimensional streamflow in a backwater area that is not well represented in this one-dimensional model.

Availability of high-resolution bathymetric and LIDAR data allowed for more detail to be added to the model and a thorough calibration, sensitivity, and verification analysis to be conducted. Model resolution and performance is most improved between RMs 140 and 160, which is collocated with the 18.3-mile reach of the Kootenai River white sturgeon critical spawning habitat. This updated model can be used to assess hydraulic characteristics of the study reach and to assist in evaluating the feasibility of habitat restoration projects.

\section{References Cited}

Barton, G.J., McDonald, R.R., Nelson, J.M., and Dinehart, R.L., 2005, Simulation of flow and sediment mobility using a multidimensional flow model for the white sturgeon critical-habitat reach, Kootenai River near Bonners Ferry, Idaho: U.S. Geological Survey Scientific Investigations Report 2005-5230, 54 p.

Barton, G.J., Moran, E.H., and Berenbrock, C., 2004, Surveying cross sections of the Kootenai River between Libby Dam, Montana, and Kootenay Lake, British Columbia, Canada: U.S. Geological Survey Open-File Report 2004-1045, 35 p. 
Barton, G.J., McDonald, R.R., and Nelson, J.M., 2009, Simulation of streamflow using a multidimensional flow model for white sturgeon habitat, Kootenai River near Bonners Ferry, Idaho-A supplement to Scientific Investigations Report 2005-5230: U.S. Geological Survey Scientific Investigations Report 2009-5026, 34 p.

Barton, G.J., Hoffman, G., McDonald, R.R., and Nelson, J.M., 2010a, Kootenai River white sturgeon critical habitat with free flowing and backwater conditions, Boundary County, Idaho-Evaluation of water depth and flow velocity during 2006-09 spawning seasons, in Proceeding in the Joint 9th Federal Interagency Sedimentation Conference and 4th Federal Interagency Hydrologic Modeling Conference, Las Vegas, Nev., June 27-July 1, 2010, 12 p.

Barton, G.J., Weakland, R.J., Ryan L.F., and Marshall L.W., 2010b, Characterizing substrate and morphology of the Kootenai River white sturgeon critical habitat, Boundary County, Idaho-Analysis for ecosystem restoration, in Proceeding in the Joint 9th Federal Interagency Sedimentation Conference and 4th Federal Interagency Hydrologic Modeling Conference, Las Vegas, Nev., June 27-July 1, 2010, 1 p.

Berenbrock, C., 2005, Simulation of hydraulic characteristics in the white sturgeon spawning habitat of the Kootenai River near Bonners Ferry, Idaho: U.S. Geological Survey Scientific Investigations Report 2005-5110, 30 p.

Berenbrock, C., 2006, Simulations of hydraulic characteristics for an upstream extension of the white sturgeon habitat of the Kootenai River near Bonners Ferry, Idaho-A supplement to Scientific Investigations Report 2005-5110: U.S. Geological Survey Scientific Investigations Report 2006-5019, 17 p.

Berenbrock, C., and Bennett, J.P., 2005, Simulation of flow and sediment transport in the white sturgeon spawning habitat of the Kootenai River near Bonners Ferry, Idaho: U.S. Geological Survey Scientific Investigations Report 2005-5173, $72 \mathrm{p}$.

Brunner, G.W., 2010a, HEC-RAS, River analysis system hydraulic reference manual: U.S. Army Corps of Engineers Hydrologic Engineering Center, CPD-69, January 2010, Version 4.1, $417 \mathrm{p}$.

Brunner, G.W., 2010b, HEC-RAS, River analysis system user's manual: U.S. Army Corps of Engineers Hydrologic Engineering Center, CPD-68, January 2010, Version 4.1, $790 \mathrm{p}$.

Fosness, R.L., and Williams, M.L., 2009, Sediment characteristics and transport in the Kootenai River white sturgeon critical habitat near Bonners Ferry, Idaho: U.S. Geological Survey Scientific Investigations Report 20095228, 40 p.
Kock, T.J., Congleton, J.L., and Anders, P.J., 2006, Effects of sediment cover on survival and development of white sturgeon embryos: North American Journal of Fisheries Management, v. 26, no. 1, p. 134-141.

Paragamian, V.L., Wakkinnen, V.D., and Crews, G., 2002, Spawning locations and movement of Kootenai River white sturgeon: Journal of Applied Ichthyology, v. 18, p. 608-616.

Paragamian, V.L., Beamesderfer, R.C., and Ireland, S.C., 2005, Status, population dynamics, and future prospects of the endangered Kootenai River white sturgeon population with and without hatchery intervention-Spawning locations and movement of Kootenai River white sturgeon: Transactions of the American Fisheries Society, v. 134, p. 518-532.

Partridge, F., 1983, Kootenai River fisheries investigation: Idaho Department of Fish and Game General Aid to Fish and Wildlife Restoration Job Completion Report F-73-R-5, variously paginated.

River Design Group, Inc., 2009, Kootenai River habitat restoration master plan: Whitefish, Montana, River Design Group, Inc., variously paginated.

Snyder, E.B., and Minshall, G.W., 1996, Ecosystem metabolism and nutrient dynamics in the Kootenai River in relation to impoundment and flow enhancement of fisheries management: Stream Ecology Center, Idaho State University, variously paginated.

Tetra Tech, Inc., 2003, Kootenai River geomorphic assessment: Seattle, Washington, Tetra Tech, Inc., 114 p.

Warner, J.C., Brunner, G.W., Wolfe, B.C., and Piper, S.S., 2010, HEC-RAS, River analysis system application guide: U.S. Army Corps of Engineers Hydrologic Engineering Center, CPD-70, January 2010, Version 4.1, 351 p.

U.S. Fish and Wildlife Service, 1999, Recovery plan for the Kootenai River population of the white sturgeon (Acipenser transmontanus): Portland, Oreg., U.S. Fish and Wildlife Service, variously paginated.

U.S. Fish and Wildlife Service, 2000, Biological opinion on effects to listed species from operation of the Federal Columbia River Power System: Portland, Oreg., U.S. Fish and Wildlife Service, variously paginated.

U.S. Fish and Wildlife Service, 2006, Biological opinion on effects to listed species from operation of the Federal Columbia River Power System: Portland, Oreg., U.S. Fish and Wildlife Service, variously paginated.

U.S. Fish and Wildlife Service, 2008, Biological opinion on effects to listed species from operation of the Federal Columbia River Power System: Portland, Oreg., U.S. Fish and Wildlife Service, variously paginated. 
Publishing support provided by the U.S. Geological Survey Publishing Network, Tacoma Publishing Service Center

For more information concerning the research in this report, contact the Director, Idaho Water Science Center

U.S. Geological Survey

230 Collins Road

Boise, Idaho 83702

http://id.water.usgs.gov

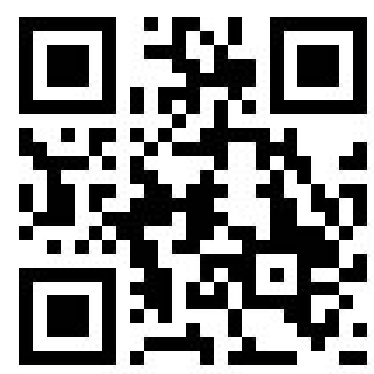


음 